OECD Working Papers on Finance, Insurance and Private Pensions No. 38

\title{
Financial Education for Migrants and their Families
}

\section{Adele Atkinson,}

Flore-Anne Messy 


\section{OECD WORKING PAPERS ON FINANCE, INSURANCE AND PRIVATE PENSIONS}

OECD Working Papers should not be reported as representing the official views of the OECD or of its member countries. The opinions expressed and arguments employed are those of the authors.

Working Papers describe preliminary results or research in progress by the author(s) and are published to stimulate discussion on a broad range of issues on which the OECD works. Comments on Working Papers are welcomed, and may be sent to (daf.contact@oecd.org) or the Financial Affairs Division, Directorate for Financial and Enterprise Affairs, OECD, 2 rue André-Pascal, 75775 Paris Cedex 16, France.

OECD Working Papers on Finance, Insurance and Private Pensions provide timely analysis and background on industry developments, structural issues, and public policy in the financial sector, including insurance and private pensions. Topics include risk management, governance, investments, benefit protection, and financial education.

This document and any map included herein are without prejudice to the status of or sovereignty over any territory, to the delimitation of international frontiers and boundaries and to the name of any territory, city or area. The statistical data for Israel are supplied by and under the responsibility of the relevant Israeli authorities. The use of such data by the OECD is without prejudice to the status of the Golan Heights, East Jerusalem and Israeli settlements in the West Bank under the terms of international law.

\section{OECD WORKING PAPERS ON FINANCE, INSURANCE AND PRIVATE PENSIONS}

are published on www.oecd.org/daf/fin/wp

(C) OECD 2015

Applications for permission to reproduce or translate all or part of this material should be made to: OECD Publishing, rights@oecd.org or by fax 33145249930. 


\title{
Financial Education for Migrants and their Families
}

\author{
by \\ Adele Atkinson and Flore-Anne Messy*
}

\begin{abstract}
Money remitted by international migrants is a major source of income for many countries around the world, exceeding all international development funds combined. Yet individual migrants and their families are often amongst the most vulnerable people in society, and many face significant barriers to the access and use of appropriate financial products.

Recognising their importance and vulnerability, some home and host countries are taking measures to support migrant workers and their families and improve their financial literacy; in some cases this occurs within the framework of a national strategy for financial education. In order to increase the extent of such support and to improve international co-operation, this paper seeks to illustrate the key challenges and suggest possible ways forward. The lessons learned will be used by the OECD and its International Network on Financial Education to develop a checklist for policy makers in order to increase the coverage of high-quality financial education for migrants.
\end{abstract}

Approved by André Laboul, Deputy Director, OECD Directorate for Financial and Enterprise Affairs

Keywords: financial education, financial inclusion, migrants, immigrants, emigrants, remittances JEL Classification: D14; D18; G28; I28; F22; F36; J61; R23

Directorate for Financial and Enterprise Affairs, OECD 


\section{TABLE OF CONTENTS}

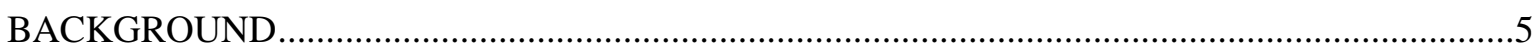

I. THE IMPORTANCE OF EMPOWERING MIGRANTS AND THEIR FAMILIES,

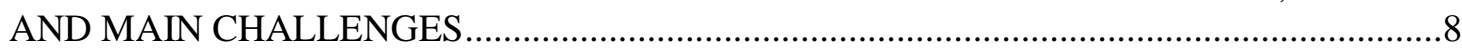

Large amounts of money flow to low income countries as remittances ........................................

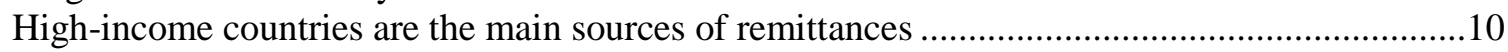

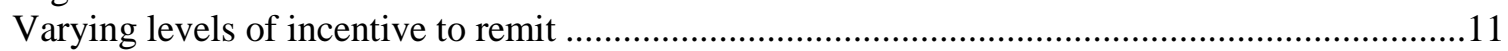

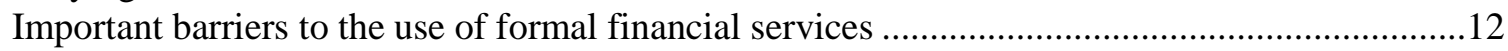

Complex money management at the family level and the need for financial education..............14

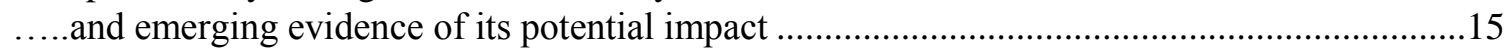

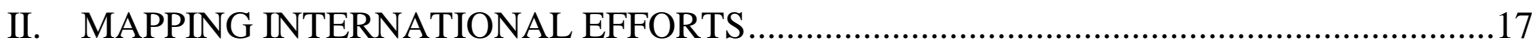

International organisations working on migration or remittances to strengthen development ......17

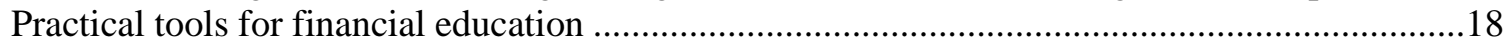

A need for strategic guidance: The purpose of this document..................................................19

III. NATIONAL FINANCIAL EDUCATION EFFORTS FOR MIGRANTS

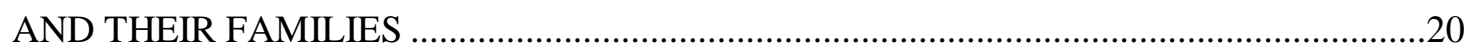

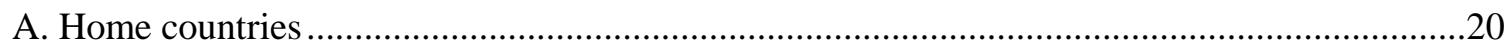

China: a new financial education strategy and continued efforts to harness remittances

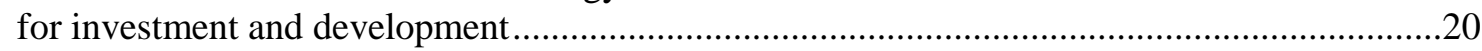

India: working extensively on financial inclusion and financial education................................22

Indonesia: targeting financial inclusion and financial education across the population ................23

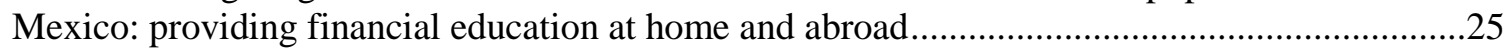

The Philippines: migrants explicitly included in National Strategy for financial education .........27

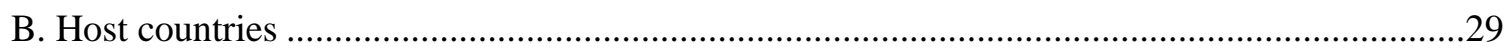

Australia: addressing the needs of arrivals from across the globe............................................29

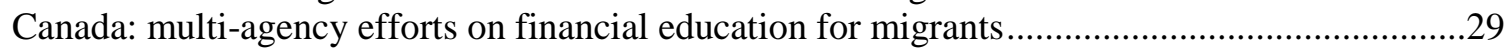

Saudi Arabia: migrants receiving support from their home countries .........................................

The United Kingdom: not-for-profit institutions providing financial education

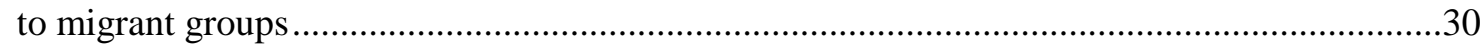

The United States: focusing on various vulnerable groups ..........................................................

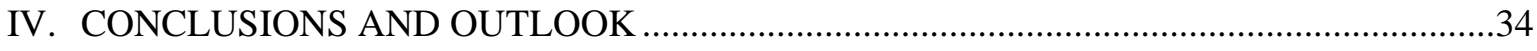

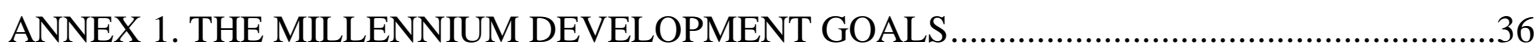

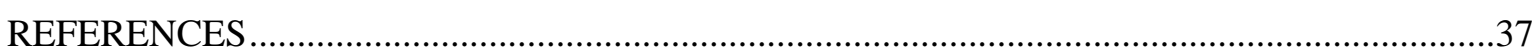

Figures

Figure 1. Top 10 recipients of remittances (USD million; 2011 estimate) …................................

Figure 2. Remittances and other resource flows to developing countries, 1990-2014 .................... 9

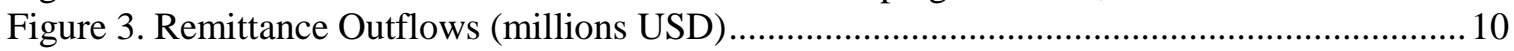

Figure 4. Top 10 Immigration countries, 2010 (no of immigrants, millions) ................................. 11 


\section{BACKGROUND}

There are an estimated 215 million international migrants ${ }^{1}$ working in a globalised economy, whom together represent a significant income stream at both the micro- and macro-economic levels, increasing financial wellbeing and household prosperity. On top of these, millions of internal migrants seeking better paid work are significantly improving national productivity and reducing poverty within countries.

Money remitted by international migrants is a major source of income for many countries around the world. In 2010, top remittance receiving countries included several in Asia, Latin America, SubSaharan Africa and the MENA region as well as the Russian Federation and ex-Soviet economies in Europe (Ratha et al, 2011). In aggregate, migrant remittances exceed all international development funds combined and are a vital component of national income in many economies, providing the opportunity for investment and growth. Of additional importance, they have been identified as a counter-cyclical source of income for home countries facing a downturn (see for example Frankel, 2009; UNDP, 2011). The documented effects of this income at the micro-economic level for the families of migrant workers include reduced risk of living in poverty, better nutrition and health, improved school attendance and even improved gender equality. Remittances have also been harnessed to fund microenterprise, including through a collective or pooled approach as used in Mexico (see Azad, 2005).

Both the economic importance and vulnerability of migrants are recognised at an international level. As a group, they are considered to be an important component in the drive to tackle poverty and meet the Millennium Development Goals (MDGs) whilst also being identified in the Road Map for the United Nations Millennium Declaration (2001) as requiring protection from discrimination and racism (Usher, 2005; see Annex 1 in this document for a list of MDGs) ${ }^{2}$.

For migrants to have a role in reducing poverty they need to have the tools, products and skills to make the most of their income, and the incentives to send money home. Yet, financial exclusion is still prevalent across the globe. Almost one in six young people and adults in developing economies are excluded (59\%), meaning that migrants' families are very likely to be outside of the formal financial sector, and migrants themselves are unlikely to have experience using financial products before they migrate. This is reflected in developed countries, where migrants face higher than average levels of exclusion. In some cases, considerable supply-side barriers exist to product take-up including strict identification requirements to meet Know Your Customer standards and the price of maintaining an account. Demand-side barriers to financial inclusion such as language barriers, low levels of financial

1 Whilst migration is widely studied, there is no universal definition of the word according to the International Organisation for Migration. The United Nations does not consider a person to be a migrant unless they have lived in a foreign country for at least 12 months. This report uses less specific criteria when discussing migrants, and the discussion covers internal as well as international migrants.

2 See also International Migration and the Millennium Development Goals: Selected papers of the UNFPA Expert Group Meeting, Morocco 2005 
literacy, lack of self-confidence and mistrust of financial institutions may also reduce the use of appropriate products among this vulnerable group.

The importance of access to financial products and services for migrants goes beyond the need to remit. Migrants also need to be able to manage money in their host country, and may require a variety of financial products and services including savings products, electronic payment facilities and access to credit and insurance. Their families may also benefit from increased financial inclusion in order to access products such as savings accounts where they can build-up savings for their own larger projects such as entrepreneurial activities or home renovation, or for use by the migrant worker on their return. Digital financial solutions, such as mobile-money and e-wallets may be of particular benefit to both migrants and their families, potentially making remittances faster, safer and less costly, and providing a more convenient and secure way to store money received.

Safe, cost-effective remittance channels and access to associated financial services in the host and home countries are seen as supply-side priorities, and the need to address all issues that may reduce migrants' abilities to access appropriate products in order to increase the flow of remittances is recognised at a high level, particularly within international endeavours to increase financial inclusion ${ }^{3}$. The 2014 G20 Australian Presidency, through the G20 Development Working Group (DWG) and Global Partnership for Financial Inclusion (GPFI - of which the OECD is an implementing partner), has announced a focus on practical actions to help developing countries, which includes helping people in low income countries to access financial services and 'benefit from reduced costs of transferring remittances home' ${ }^{4}$. This follows from a 2009 goal set by G8 leaders to 'aim to make financial services more accessible to migrants and to those who receive remittances in the developing world. We will work to achieve in particular the objective of a reduction of the global average costs of transferring remittances from the present 10\% to 5\% in 5 years through enhanced information, transparency, competition and cooperation with partners, generating a significant net increase in income for migrants and their families in the developing world ${ }^{5}$.

The OECD, through its International Network on Financial Education (INFE), and the G20, through the GPFI subgroup on Financial Literacy and Financial Consumer Protection, are also addressing demand-side barriers to financial inclusion, and the specific needs of migrants. Migrants are identified as a potential target group for financial education in the OECD/INFE High-level Principles on National Strategies for Financial Education, approved by G20 leaders in 2012 (OECD, 2012a $)^{6}$. The 2013 OECD publication 'Promoting Financial Inclusion through Financial Education: OECD/INFE Evidence, Policies and Practice' is also an important component of the OECD work, stressing the fact that financial literacy skills not only facilitate financial inclusion, but are also vital

3 The OECD/INFE defines financial inclusion as follows 'Financial inclusion refers to the process of promoting affordable, timely and adequate access to a wide range of regulated financial products and services and broadening their use by all segments of society through the implementation of tailored existing and innovative approaches including financial awareness and education with a view to promote financial well-being as well as economic and social inclusion.' (Atkinson and Messy, 2013).

https://www.g20.org/news/g20_maps_out_its_plans_support_developing_countries_under_australia\%E2\% 80\%99s 2014_presidency

5 http://www.g8italia2009.it/static/G8_Allegato/G8 Declaration_08 07 09 final,0.pdf

$6 \quad$ In principle, a NS should aim to ensure that all segments of the population become financially literate. In practice and according to national circumstances and identified needs, this may mean targeting specific (vulnerable) groups with more intensive interventions or greater resources. Such groups may include elderly populations, youth, migrants, low income groups, women, workers, the unemployed as well as communities speaking a different language and ethnic groups ${ }^{6}$ (our emphasis). 
for effective money management and long-term financial planning and that such behaviours can significantly improve financial wellbeing.

\section{This paper}

This paper draws primarily on desk-research, whilst also taking into account responses to previous OECD/INFE member surveys where relevant (including those on financial education for financial inclusion, and national strategies for financial education), to consider the importance of targeting financial education efforts on migrants and their families, and to describe illustrative case studies in 10 countries with different approaches to supporting migrants and/or their families. It has benefited from feedback from INFE members at their meetings in Paris in 2013 and Istanbul in 2014, as well as through the written process.

It provides an important complement to the international supply-side initiatives to increase financial inclusion and lower the cost of remittances for migrants and their families by focusing on demand-side barriers to financial inclusion, thereby feeding into the GPFI and its subgroup on Financial Literacy and Financial Consumer Protection. It also provides valuable detail about the needs of migrants as a target group for financial education, to support the implementation of the OECD/INFE High-level Principles on National Strategies for Financial Education, endorsed by G20 leaders in 2012 (OECD, 2012a).

Section I starts by highlighting the size of the remittance flows between migrants and their families and discussing the potential benefits of empowering these two groups through financial education.

Section II explores the international efforts to influence policy and practice in relation to financial education for migrants. In Section III the paper looks at existing policy and practice at a national level in five countries receiving large amounts in remittances, China, India, Indonesia, Mexico and the Philippines and five countries that host large numbers of migrant workers: Australia, Canada, Saudi Arabia, the United Kingdom and the United States.

Section IV discusses the lessons that can be learned from the case studies presented. 


\title{
I. THE IMPORTANCE OF EMPOWERING MIGRANTS AND THEIR FAMILIES, AND MAIN CHALLENGES
}

\begin{abstract}
Migration is not a new phenomenon; indeed throughout history people have moved in search of improved resources, security and work, often crossing borders and oceans in search of new horizons and better standards of living. Current estimates indicate that one in seven individuals in the world is currently a migrant (having migrated internally or across borders) ${ }^{7}$. Migrants are typically classified according to whether or not they are moving for economic reasons. Economic migrants include the whole spectrum of workers, from the highly qualified to the uneducated; those who move to a different country to start a new life -often with family- and have no intention of returning; labourers and farmhands who stay in one place for short periods of time to seek seasonal work or undertake specific projects, and those who travel alone without specific employment in mind, in the hope of being able to send money home to family or save for their own future. Many will have left family members at home; but some will have split their family - maybe travelling with their spouse but leaving their children with other family members. Some of those moving across national borders have appropriate paperwork and stay within the country legally, while others have entered or stayed without legal entitlement; some may be working in the formal sector whilst others seek work or create their own opportunities within the informal sector.
\end{abstract}

Economic migrants, and particularly those from developing economies, can provide a much needed addition to household income in their home country, and it is now widely recognised that migrants' remittances have important potential for reducing poverty. However, the costs and difficulties faced when sending money home and a lack of financial literacy amongst migrants and their families can seriously reduce the amount of money available to the recipient, and thus create barriers to poverty reduction and greater financial wellbeing. This is especially likely to be the case when informal remittance channels are used, which can be both expensive and very high risk (Romagnoli and Sie, 2012).

This paper is particularly directed at understanding the needs of internal and international economic migrants who could potentially send money home and families expecting to receive money ${ }^{8}$. For convenience, the text will refer to this group as 'migrant workers and their families'.

\section{Large amounts of money flow to low income countries as remittances}

Research carried out by the World Bank (Ratha et al, 2011) shows that officially-recorded remittance flows to developing countries were estimated to have reached USD 372 billion in 2011. By 2012, annual receipts for India alone amounted to USD 67 million, the largest amount received by one country (Figure 1$)^{9}$. It should be remembered, that this only represents a proportion of the overall amount remitted annually to most countries, as many migrants currently use informal forms of

\footnotetext{
World Bank, 2014
}

8 It is worth keeping in mind that migrants may have no legal obligation to support their family; their decision to do so is often largely a moral and/or practical decision.

9 Estimates and records from different sources on the number of migrants and amounts remitted should be compared with caution as they are calculated in different ways using a variety of data and methods. 
payment that are not recorded in official statistics. In addition, large amounts of money flow internally, with the potential to reduce poverty in the poorer regions.

Figure 1. Top 10 recipients of remittances, 2012 (USD billion)

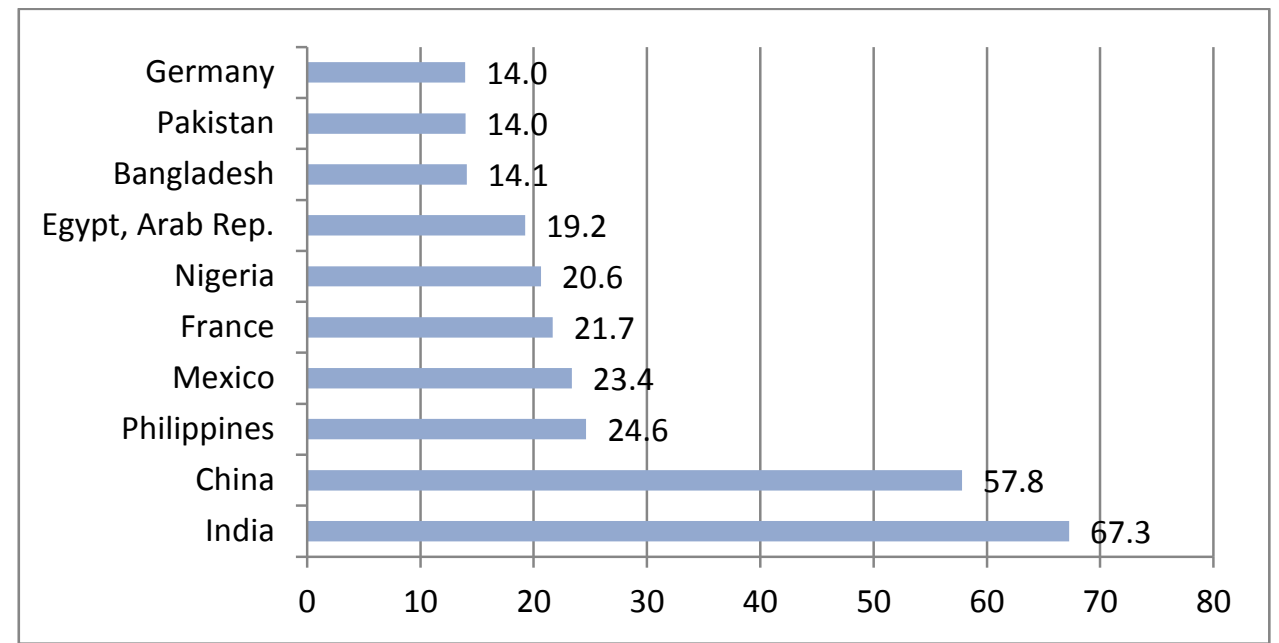

Source: World Bank, accessed 7 April 2014

http://siteresources.worldbank.org/INTPROSPECTS/Resources/334934-

1288990760745/RemittanceData Inflows Oct2013.xIs

Remittances have far exceeded the growth in official development assistance (ODA) to developing countries (See Figure 2) and it is expected that there will be worldwide remittance flows of USD 615 billion in 2014, with money going to developing countries making up USD 467 billion of the world total (World Bank, 2012).

Figure 2. Remittances and other resource flows to developing countries, 1990-2014

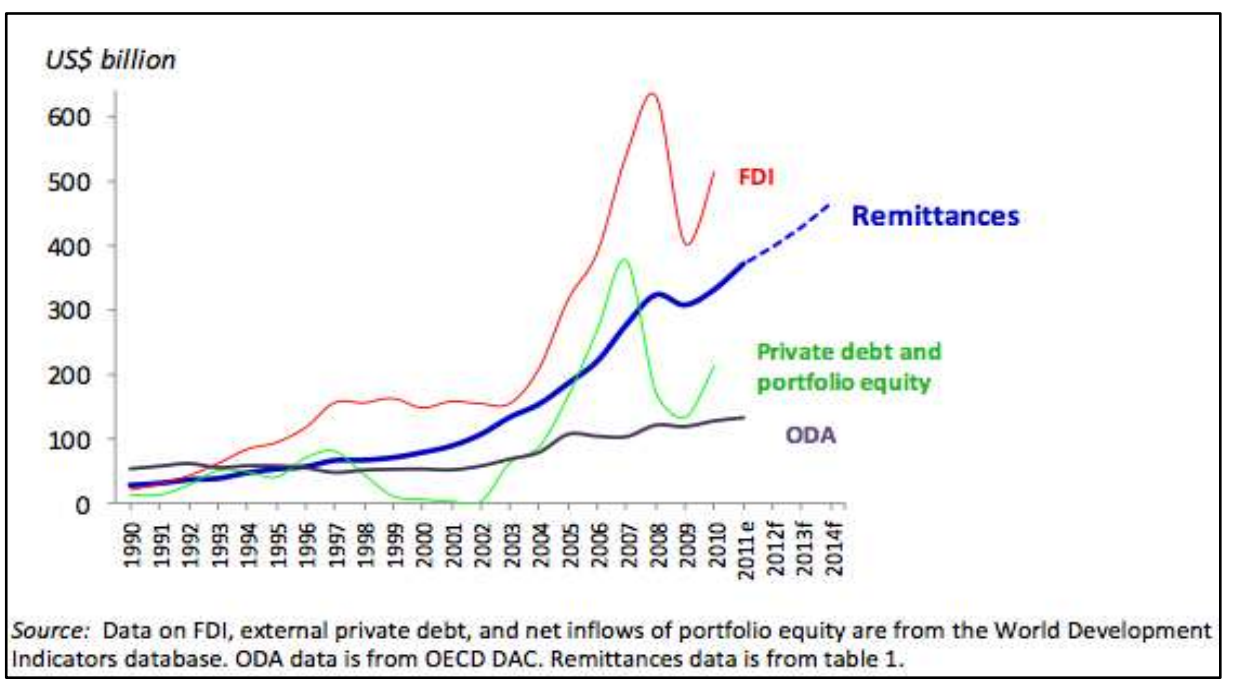

Notes: $\mathrm{FDI}=$ Foreign Direct Investment, ODA= Official development assistance: Source World Bank 2012 Migration and Development Brief 18 


\section{High-income countries are the main sources of remittances}

Unsurprisingly, large, relatively high-income countries are the main source of remittances (Figure 3). The United States is by far the largest, with USD 51 billion in recorded outward flows in 2012, followed by the Russian Federation at USD 32 billion. However, smaller countries such as Saudi Arabia, Switzerland and Kuwait are also major sources of remittances.

Figure 3. Top 10 remittance Outflows, 2012 (USD billions)

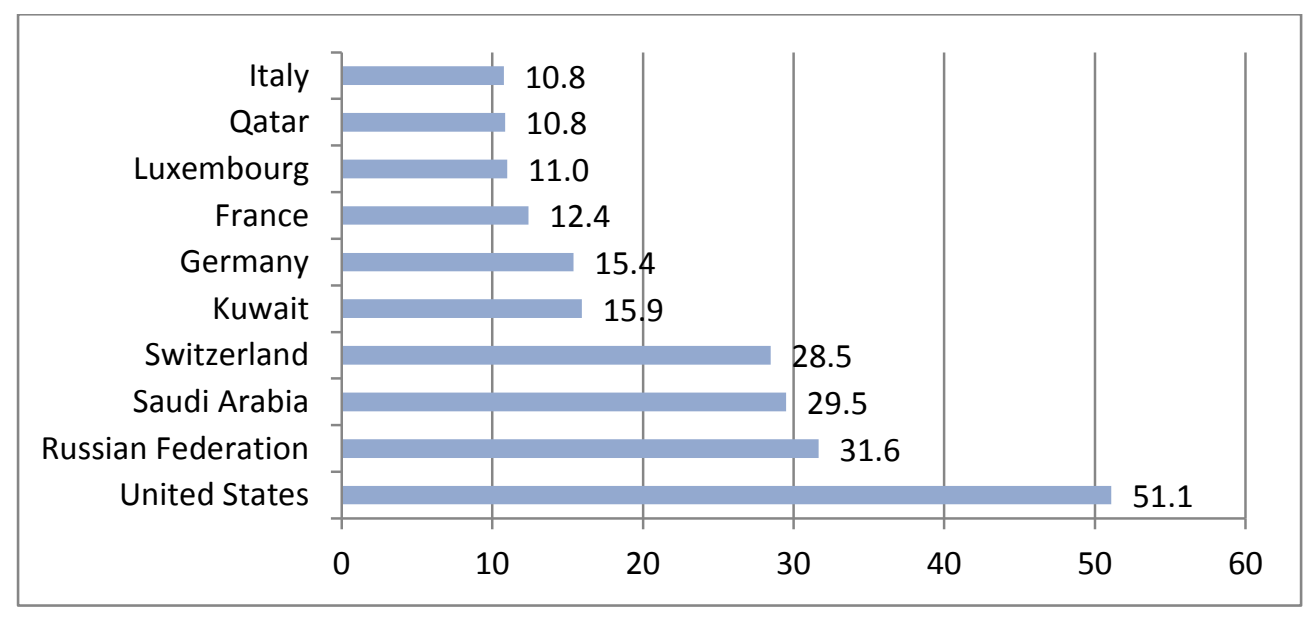

Source: World Bank, accessed 7 April 2014:

http://siteresources.worldbank.org/INTPROSPECTS/Resources/334934-

1288990760745/RemittanceData_Outflows_Oct2013.xls

There are some noteworthy differences in the top 10 host countries in terms of overall number of migrants and remittance outflows (Figure 4). Countries such as Qatar, Italy and Switzerland have large remittance outflows but their immigrant populations are not amongst the 10 largest (indicating that their migrant workers are high earners relative to migrants elsewhere). Furthermore, the difference between the number of migrants going to The Russian Federation (11 million) and the US (46 million), is much greater than the difference in the size of remittance outflows from these two countries ( 32 billion and 51 billion respectively), suggesting that considerably more money is remitted per immigrant in Russia ${ }^{10}$.

Data also indicate that the United States had more immigrants in 2013 than either Western Asia or Western Europe or the whole of Africa (United Nations, 2013).

10 However, data discrepancies cannot be ruled out, particularly as the amount of outflows in 2009 was recorded as 18.6 billion (Ratha et al, 2011). Note also that some variation could result from exchange rate fluctuations. 
Figure 4. Top 10 Immigration countries, 2010 (no. of immigrants, millions)

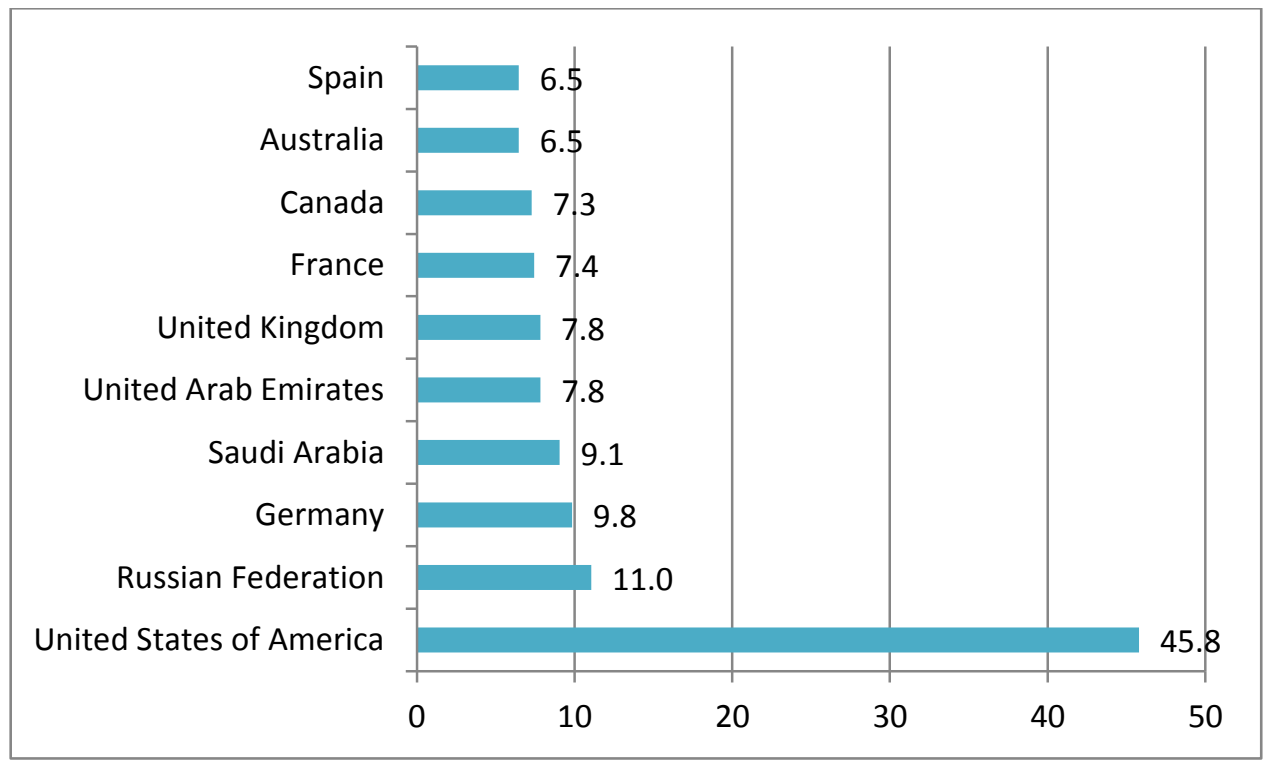

Source: United Nations, Department of Economic and Social Affairs (2013). Trends in International Migrant Stock: The 2013 revision (United Nations database, POP/DB/MIG/Stock/Rev.2013). Accessed 7 April 2014

http://esa.un.org/unmigration/TIMSA2013/data/UN MigrantStock 2013.xls

\section{Varying levels of incentive to remit}

Whilst remittances are an important source of income to many families and represent a large part of overall inflows in some countries, the incentives and legal frameworks for remitting vary widely. The greatest incentive may not be external, but may come from the desire to support family or repay debts, whilst some migrants may also see remitting as an investment in their own future. However, governments also have a role to play. In China, for example, the government has changed the law to give families the right to receive money from overseas. Elsewhere government intervention has increased the investment motive: migrants from India and Israel for example can invest in diaspora bonds in their home country, benefiting their home country and providing them with a useful savings vehicle. Countries such as Pakistan, Bangladesh and India also offer foreign currency denominated bonds (GIZ, 2012; Meiji Fatunla, 2013; Puri and Ritzema, 1999, Vezzoli and Lacroix, 2010).

There are also potential disincentives to remitting, depending on the countries involved, including the cost of sending money ${ }^{11}$, unfavourable exchange rates, interest rates on savings in home and host countries and the trustworthiness of the remittance channels and financial services sector of the relevant countries. Migrant workers seeking to support their family may prefer to send home gifts and practical items rather than money in order to mitigate some (but by no means all) of these risks, or may choose to make relatively frequent visits home in order to make payments in person (and a combination of such approaches is probable in many cases - see for example Nandhi and Deepti, 2013). Research suggests that meeting the needs of family can impact on migrants' decisions to send the maximum amount affordable as remittances in both positive and negative ways. Whilst migrants may have moved with the intention of supporting their immediate household for example, they may also come to recognise that there are other expectations on them or obligations such as providing for

11 Average remittance costs worldwide dropped to $8.4 \%$ in 2014 , but were as high as $12 \%$ in sub-Saharan Africa (World Bank, 2014). 
their parents or paying for the migration of other family members. Some may resent being expected to support their extended family (such as siblings, parents or in-laws) or they may wish to give less to some than others. They may also mistrust certain members of the family who could access any money sent $^{12}$.

\section{Important barriers to the use of formal financial services}

Several barriers are likely to hinder access to, and use of, formal financial services amongst migrants and their families. Many of these reflect the general barriers to financial inclusion (Atkinson and Messy, 2013), but certain barriers are more pronounced, including a lack of documentation (Orozco and Jewers, 2014).

Barriers to inclusion for migrants and their families may include:

1. Underdeveloped financial services industry and financial consumer protection in the home or host country

- Lack of a financial services industry in the home country or village: The most important barrier to the use of formal services may be a lack of relevant products in the home country. This has consequences for migrants and their families: 1) as a result of the lack of access at home new migrants will not have experience in dealing with financial institutions and may not recognise the benefits of using formal products whilst 2) the family will not be able to access the products that could help them to handle remittance receipts and manage the money safely.

- Lack of infrastructure: A lack of bank branches or other points of access to existing financial service providers can create an important barrier for migrant workers. This is particularly likely to be a problem for those working in remote locations or living in low-income urban areas.

- Lack of appropriate products for migrants in their host country or town: Migrant workers may not find the products that they require to manage their money or send remittances ${ }^{13}$.

- Unsatisfactory product design and terms and conditions: Even when products exist, high transaction fees, lack of deposit insurance, limited variety or low-flexibility of financial services may deter individuals from seeking access.

- Onerous documentation requirements designed to prevent money laundering and terrorism funding, including proof of residency, may make access impossible regardless of legal status. Migrants often live in shared accommodation and have insufficient forms of identification to satisfy such requirements.

12 For further discussion about the decision making process amongst Chinese migrants specifically, see Murphy, 2006 and for migrants from Latin America and the Caribbean see Orozco and Jewers, 2014. See Ashraf et al (2011) for a randomised experiment testing different levels of control over household savings.

13 Whilst it is recognised that important work is also ongoing to develop safe, low-cost remittance channels and financial products, and price comparison tools for such products, a discussion of these is beyond the scope of this paper. 
- Lack of a transparent, accessible complaints handling procedures: A lack of a clear financial consumer protection framework may deter migrants. They may also be deterred by stories of problems faced by other customers that are not dealt with in a fair and transparent manner, even if the issues causing these problems have since been dealt with.

\section{Cultural and social attitudes, trust and confidence}

- Lack of familiarity with the system: Financial systems vary across countries (and even within countries to some extent), and unfamiliar financial services providers can make migrants lack confidence in seeking advice or buying suitable products and make it difficult to know where to go for help (such situations are described by organisations working with Latin American migrants in the US for example).

- Cultural or religious differences as well as prejudice or the fear of prejudice can also create obstacles for migrants trying to purchase financial products. Social relationships and commitments with informal providers have also been shown to have an impact on formal financial inclusion.

- Mistrust of financial services: Individuals may be dissuaded from using formal financial services if they do not believe that the financial services sector is reliable and well regulated. Such mistrust may come from first-hand experience in the home or host country or may develop from hearing stories from other migrants and their families.

- Misunderstanding or mistrust about the role of the banking sector in identifying illegal immigration: Undocumented migrants or those remaining in their host country once their visa has expired may be concerned that if they identify themselves to formal institutions they will risk being punished or deported.

- Visibility/transparency of transactions: The extent to which money can be traced may also create additional barriers for households who do not want to let others know how much money they are sending or receiving. This could be for a number of reasons including not wanting to put the family at risk from robbery, tax avoidance/evasion or illegal activity.

3. Knowledge, confidence and skills, including relevant education

- $\quad$ Limited language skills or low levels of literacy and numeracy: migrants can face real and imagined barriers to accessing financial products when they are uncomfortable speaking the language of their host country or using the technical language of finance. Those who struggle to read at all, or have not mastered the alphabet in their host country, and those who cannot manage basic mathematical functions will struggle more than others.

- Lack of confidence, experience or ability to access telecommunications and internet technology: If migrants and their families do not have a mobile phone or 
private, secure access to the internet they may not be able to benefit from newer technologies designed to increase financial inclusion ${ }^{14}$.

- Low levels of financial literacy: Low levels of financial literacy amongst migrants and their families may also create further barriers to access as they struggle to understand the terms used in financial services and the features of different financial products. Low levels of financial literacy can also result in low levels of confidence when choosing across financial providers and products and can leave individuals particularly susceptible to fraud and mis-information.

- Inadequate provision of financial education: financial education programmes may not be sufficiently tailored to the needs of migrant workers and their families to improve their financial literacy and increase their access to appropriate financial products. Where programmes have been developed for a local audience they may not consider the international dimension of migrants, and may not be sufficiently culturally sensitive.

Research also indicates that, for many migrants, a lack of time also makes it difficult for them to research alternative approaches, seek advice, or make payments through more distant providers. For low-income workers who are paid by the hour, the opportunity cost of stopping work in order to address such issues is particularly acute.

\section{Complex money management at the family level and the need for financial education...}

Irrespective of product use, migrants and their families need to be able to effectively manage their financial situation, income and expenses. Even if all transactions are undertaken in cash it is beneficial for the migrant and their family to understand and know how to calculate exchange rates, to know how to budget and make effective use of the money they have, how to keep records of money sent and received, and how to smooth irregular cash flows. They should also be aware of the fees they are paying to make money transfers even when sending cash through informal channels, and how these are being deducted from the final amount received in the home country. Managing the uncertainty of varying inflation in home and host country may also be important and it may be necessary to understand the tax implications of different financial decisions.

The vast majority of migrants and their families could benefit from access to - and a thorough understanding of - a range of financial products, including remittance mechanisms, current accounts, insurance, long-term savings products and credit.

For some migrants and their families, a thorough understanding of credit may be the most urgent, including calculating the amount outstanding, understanding the impact of interest payments and knowing when to prioritise repayments over other financial demands. This is particularly important when migrant workers arrive in their host country with an outstanding debt caused by borrowing money to pay an agent or buy travel tickets; it is also invaluable for those migrant workers who might consider borrowing money to send home to family ${ }^{15}$ or for use in their host country (on accommodation or transport costs for example).

14 This also poses a risk to the excluded, who may resort to sharing their personal information with third parties in order to gain some level of access, or use shared computers without fully understanding how to keep their information and transactions secure.

15 For discussion of the pressures on migrants to take out loans to send additional money home see, for example, Consumers International (2012). 
For migrants with a partner, joint money management may also require new competencies. A study of Latin American and Caribbean migrants in the US found that in a third of cases, remittance receipts were the only source of income for their family back home (Orozco and Jewers, 2014). This puts a huge pressure on the migrant to continue to send money home regardless of employment prospects or expenditure, but also requires excellent money management skills for the recipient in the home country. Such complex, transnational household money management requires negotiation, discussion and financial control on the part of both partners (see for example Seshan and Yang, 2012). This can be particularly difficult for migrants to achieve given the physical separation and other hurdles such as time differences and costs of staying in touch, further reinforcing their need for information and education before and during their separation in order to help them manage this situation efficiently.

The children of migrants also stand to benefit from receiving financial education themselves and from having better informed parents. New findings from the OECD PISA exercise show that the immigrant status of 15-year-olds (based on whether they or at least one of their parents was born abroad) is associated with their performance in financial literacy. On average across the 13 OECD countries and economies studied, students without an immigrant background achieve 37 points more than students with an immigrant background, and some of this difference remains even when comparing across students who speak the same language at home and have a similar socio-economic background, maths and reading performance (OECD (2014)).

The provision of both improved financial inclusion and good quality financial education for migrants and their families as complements to financial consumer protection and regulation therefore appears to be a priority in any attempt to harness remittances for poverty reduction, financial wellbeing and financial stability. Financial education can offer immediate benefits to individuals and households wanting to improve their money management skills whilst supply-side financial inclusion efforts such as digital finance, reduced remittance fees and micro-finance services can increase access, but require parallel demand-side efforts, including financial education, to maximise their impact.

\section{......and emerging evidence of its potential impact}

There is a burgeoning interest in collecting information about the provision of financial education for migrants, and a small number of evaluation reports from financial education programmes targeted at migrants and their families are now available. These include some undertaken as part of a much broader project on financial education undertaken by the World Bank and field partners under the Russia Trust Fund for Financial Literacy ${ }^{16}$.

Seshan and Yang (2014) found noticeable impact from a single financial education seminar held for Indian migrants in Qatar ${ }^{17}$, with the largest change observed amongst those who originally had low levels of savings. Their findings indicate the benefit of financial education to those who stand to benefit the most, and the authors also suggest that more targeted financial education programmes may have better outcomes across all migrants. In Australia and New Zealand, the World Bank provided guidance on choosing remittance products to workers who had migrated from the Pacific Islands, East Asia, and Sri Lanka. Whilst this increased knowledge it did not have discernable impact on the use of cheaper remittance products, or on the amount and frequency of sending money home (Gibson et al, 2012). In contrast, in Indonesia, the World Bank partnered with the Government to undertake a randomised trial to induce savings amongst migrants through financial education aimed either at

\footnotetext{
$16 \quad$ www.finlitedu.org

17 Further information is provided in the section on India
} 
migrants, the families of migrants, or both the migrant and their family (Doi et al, 2012) ${ }^{18}$. The findings support the effort to target both migrants and their families, showing large behaviour changes in terms of saving and borrowing - with more of the remittances being saved by families, and a lower reliance on credit amongst migrant workers. Knowledge was also shown to increase.

18 Note however, that the majority of migrants in this study were female; other studies may find different results. See also Jakarta Post, October 292012 http://www.thejakartapost.com/news/2012/10/29/financialliteracy-helping-overseas-migrant-workers-create-wealth.html 


\section{MAPPING INTERNATIONAL EFFORTS}

This section provides a brief mapping of relevant efforts undertaken by international organisations focusing on remittances, migration or development and identifies how the OECD/INFE and its expert subgroup can make a valuable contribution by focusing attention on the financial education needs of migrants and their families in home and host countries.

\section{International organisations working on migration or remittances to strengthen development}

High-level policy efforts are underway to address financial access issues, including actions designed to reduce the costs of remittance payments for migrants and the importance of migration and the consequent need to support migrants and their families is widely recognised as discussed in the Background to this paper ${ }^{19}$. Furthermore, several international organisations currently work on policy related to migrants and/or remittances. For example, the OECD Development Centre, with support from the European Commission, undertakes work on the interrelation between public policies, migration and development, and has hosted meetings in a wide range of remittance receiving countries including Cambodia and Haiti. In 2004, the International Labour Conference of the International Labour Organisation (ILO) adopted a Multilateral Framework on Labour Migration which is now part of the ILO action plan to ensure that migration contributes to growth ${ }^{20}$. The World Bank has ongoing work on the economic impact of migrants and remittances, and related policy challenges including through the Payment Systems Development Group. In addition the G20 workstream on Growth with Resilience includes a Global Remittances Working Group. The International Fund for Agricultural Development, a specialised United Nations agency, has a multi-million dollar multi-donor facility, Financing Facility for Remittances, which aims to increase economic opportunities for rural poor through the support and development of innovative, cost-effective, and easily accessible remittance services $^{21}$.

Europe-aid, the international aid fund of the European Commission ran a Migration and Asylum Thematic Programme for co-operation with countries in and beyond Europe, from 2007 to $2013^{22}$. This fund included efforts to foster development and primarily funds projects aimed at supporting or improving the rights of migrants but did not explicitly focus on the financial education and product needs of this group.

There are also several international organisations that specifically focus on policy and research relating to migrants and remittances. These include the International Organization for Migration (IOM) whose mission statement includes advancing understanding of migration issues and the

19 This paper focuses entirely on polices aimed at supporting migrants and their families directly or the infrastructure needed to ensure their financial wellbeing, national development and financial stability; it does not discuss organisations working exclusively on topics such as illegal migration or refugee and asylum policies.

20 http://www.ilo.org/global/topics/labour-migration/lang--en/index.htm

21 See http://www.ifad.org/remittances/index.htm

22 http://ec.europa.eu/europeaid/how/finance/dci/migration_en.htm 
encouragement of social and economic development through migration ${ }^{23}$, and the US based Migration Policy Institute which develops, analyses and evaluates policies related to migration and refugees ${ }^{24}$.

\section{Practical tools for financial education}

Several organisations have identified the potential benefit of providing migrants and/or their families with financial education, and various practical tools exist. Initiatives at the international level typically bundle aspects of financial education with various other education and services, rather than explicitly addressing financial literacy. IOM for example, stresses the importance of pre-departure training for migrant workers and their families (including navigation of new financial systems) and encourages co-ordination between education providers in host and home countries ${ }^{25}$.

Practical programmes implemented by IOM include joint efforts to educate the Philippine diaspora in Italy under the Overseas Filipino Workers (OFWs) initiative from the Bangko Sentral ng Pilipinas (see Section III for more detail of financial education for migrants and their families in the Philippines $)^{26}$.

The International Labour Organization (ILO) in partnership with Microfinance Opportunities has developed a detailed training package which is expected to help organisations to teach (prospective) migrant workers and their families about money and how to use it wisely (ILO, 2011). The package focuses on knowledge and skills relating to financial behaviours such as spending and budgeting and to various financial products including insurance. It includes materials for trainers, migrants and migrant families, and comprises a 400 page training manual which starts with the decision to migrate, and includes sections on job choices, employment contracts and making plans to return home as well as practical guidance on meeting with financial institutions, recognising fake money, saving and taking out insurance.

$\mathrm{GIZ}^{27}$, the implementing agency of the German Federal Ministry, has created a valuable handbook on financial literacy for remittances and diaspora investments, which builds on new and existing research to guide projects designed to support financial inclusion and financial education amongst migrants and their families (GIZ, 2012). The document focuses on the processes and practical issues around making programmes work and provides an important complement to training packages such as that developed by ILO. It also offers a wide ranging summary of relevant financial literacy projects, creating opportunities for partnership or replication.

There are also other practical resources aimed at providing financial education to low-income groups that may benefit migrants and their families. These are too many to list individually, but include contributions from international organisations such as the Microfinance Centre which works

\footnotetext{
23 http://www.iom.int

24 http://www.migrationpolicy.org/

25 IOM, Best Practices: IOM’s Migrant Training / Pre-departure Orientation Programs http://www.iom.int/jahia/webdav/shared/shared/mainsite/activities/facilitating/Best-Practices-MigrantTraining.pdf

26 http://www.atikha.org/news/training-of-trainers-on-financial-literacy-rebuild-resources-back-for-familycommunity-and-country.html

27 Deutsche Gesellshaft fur Internationale Zusammenarbeit www.giz.de
} 
across 27 countries in Europe and Asia, and offers training modules on relevant topics such as Remittances and Plan your Future ${ }^{28}$.

Such tools are essential, but now need complementing with policies that provide comprehensive support to migrants and their families in home and host countries.

\section{A need for strategic guidance: The purpose of this document}

It is clear that more work is needed to fully exploit the potential benefit of financial education for migrants and their families. The OECD and its International Network on Financial Education (INFE) has already developed High-level Principles on National Strategies for Financial Education that indicate the importance of considering migrants as a target group for initiatives. This document provides a valuable addition to the High-level Principles, exploring appropriate policy responses to the challenge of working on this subject and identifying and disseminating good practices that can integrate provision across countries and continents.

In particular, it highlights ways in which countries have successfully developed financial education initiatives and cooperated to support migrants and their families in home and host countries as well as identifying and promoting evaluation efforts, innovative approaches and good practices.

28 http://www.mfc.org.pl/en/content/modules 


\section{NATIONAL FINANCIAL EDUCATION EFFORTS FOR MIGRANTS AND THEIR FAMILIES}

This section reviews the current provision of financial education in ten countries with large numbers of immigrants or emigrants; in particular discussing the various ways in which policy makers and others are currently supporting migrants and their families in order to improve levels of financial literacy and maximise the benefit of remittance receipts. The case studies presented below draw on a range of publically available information produced in the English language or un-published information submitted to the OECD/INFE by country representatives. As such, they offer an overview of some of the provision available for migrants and their families, but are not intended to provide a comprehensive summary of all available, relevant financial education programmes.

Reporting focuses on both home and host countries. Five home countries receiving large sums in remittances are covered: China (USD 58 billion), India(USD 67 billion), Indonesia (USD 7 billion), Mexico (USD 23 billion) and the Philippines (USD 25 billion) (Figure $1^{29}$ ), as well as five countries with large numbers of immigrants: Australia, (6.5 million) Canada (7.3 million), Saudi Arabia (9.1 million), the United Kingdom (7.8 million), and the United States (45.8 million) (Figure 4).

\section{A. Home countries}

\section{China: a new financial education strategy and continued efforts to harness remittances for investment and development}

Almost 0.6 percent of the Chinese population lived overseas as migrants in 2010 (stock of emigrants: 8.3 million, Ratha et al, 2011). The education level of Chinese migrant workers is high, particularly among younger generations, and they often seek work in Australia, Canada, New Zealand or the United States.

Internal migration is also an official government policy as part of the move to eradicate rural poverty, with the target that every rural household should have at least one member working outside of farming (Murphy, 2006). China's population of internal migrants was reported to be 253 million in 2011 , or $33 \%$ of all employed workers in the country; seven million of these live in the capital, Beijing (National Bureau of Statistics of China, 2012; Hays, 2012). It is estimated that internal migrants sent home USD 30 billion in 2005 (Cheng and Zong, 2005 cited in Murphy, 2006). Many of them have low levels of general literacy, and would benefit from financial education as they find it difficult to understand financial products (Cheng and $\mathrm{Xu}, 2005$ ).

Since 1992, the not-for-profit China Foundation for Development of Financial Education foundation has been active in delivering financial education workshop and seminars for the general public and as part of a process to alleviate poverty in rural areas in China. The importance of efforts such as this has been recognised by the People's Bank of China, which is currently leading the process of planning and designing a National Strategy for Financial Education in China, in order to better

29 Data on Indonesia not shown in Figure 1 but drawn from the same source. 
coordinate existing activities and improve financial literacy in the country ${ }^{30}$. Financial consumer protection agencies will have responsibility for the activities within this strategy, which will include improving financial inclusion and meeting the financial education needs of low-income groups.

The plan for the national strategy indicates that one of the main policy priorities is to protect disadvantage groups, including migrant labour and the China Banking Regulatory Commission (CBRC) has already begun working with banks to establish a public education service, providing free financial literacy materials and other resources as well as providing migrant workers with financial education to guard against financial risks (G20/OECD, 2013).

Whilst financial education is rising up the agenda in China, previously the Chinese Government's efforts reflected the fact that they recognised the benefits of migrant remittances for economic growth through business investment and development. The 1990 Law on the Protection of the Rights and Interests of Returned Overseas and Relatives of Overseas Chinese gave family members in China the right to receive remittances from overseas, and ordered local governments to support their efforts to establish commercial, industrial or agricultural ventures. These efforts are intended to directly contribute to China's economic development and job creation. Local officials have also encouraged migrant families to invest in their villages. They have simplified the process and regulation of investment, and made concessions in taxes and fees to encourage investment (Economist Intelligence Unit, 2008).

The presence of formal remittance channels such as rural credit cooperatives and post offices appear to be low and declining in village locations and therefore unlikely to benefit migrant workers' families in remote areas (Murphy, 2006). However, a USD 300,000 project designed by the Yunnan Institute of Development (YID) is underway to try to address this issue in Yunnan Province with a combination of door-to-door financial services and financial education aimed at 1,500 migrant workers and their rural, farming families in receipt of remittances ${ }^{31}$. As part of the project, which aims to direct more money into income generation activities, a remittance-record product has been designed to assist farmers in obtaining micro-credit, by showing their credit-worthiness. The Financing Facility for Remittances is also working with the YID to encourage such community based organisations to share good practices in relation to financial literacy ${ }^{32}$.

The China Banking Regulatory Commission, Inno, a not-for-profit community development organisation and Visa, a global payment company, also launched a joint financial education initiative in 2008 , to provide financial education and financial inclusion in the poorest regions of central and western China. The programme is designed to reach rural inhabitants, including the families of migrant workers, providing basic financial knowledge from a financial literacy bus and building a two tier network of volunteers (where the top tier typically consists of employees from financial institutions who in turn train other volunteers; this approach is sometimes also described as 'cascading'). It was originally piloted in four counties and then rolled out to a total of 67 counties; by

30 Information supplied in response to OECD/INFE member survey, 2014 and presentation at the OECD/Korea High-level Symposium on Financial Education in Seoul 2014.

31 According to IFAD, the financial cost of remitting in China is not high, but it can take a whole day to travel to a financial institution and back without such services.

http://www.ifad.org/remittances/projects/asia/china.htm

32 IFAD, Remittances and Financial Literacy, http://www.ifad.org/remittances/pub/financial.pdf 
June 2013 it had reached 920,000 farmers. In order to ensure sustainability, local innovative financial education projects are encouraged through the Visa Rural Financial Education Innovation Award ${ }^{33}$.

\section{India: working extensively on financial inclusion and financial education}

Just under $1 \%$ of the Indian population lived overseas as migrants in 2010 (stock of emigrants: 11.3 million; Ratha et al, 2011). Top destination countries are the United States (providing 38\% of international remittance inflows in 2009-10: Reserve Bank of India [RBI], 2010), the United Arab Emirates, Saudi Arabia and Bangladesh. Unskilled and semi-skilled temporary workers typically migrate to the Middle East and Southeast Asia whilst highly-skilled professional workers (who tend to move on a permanent basis) migrate to industrial countries (Afram, 2012). India also has a very large number of internal migrants who seek to remit income to family in distant regions and who often face social and financial exclusion and have unmet needs for formal financial services (UNICEF, 2012, Afram, 2012, Garg et al, 2009) ${ }^{34}$.

\section{Financial education within India}

In 2013, India formed a Technical Group for financial inclusion and financial literacy under the Financial Stability and Development Council (FSCD), and formulated a National Strategy for Financial Education with a five year time frame and a target of reaching 500 million inhabitants. The country has identified financial education as integral in achieving financial inclusion, financial stability and consumer protection. Migrants are a target group of the strategy, and products are being designed specifically to meet their needs ${ }^{35}$.

\section{Support for Indian migrant workers worldwide}

In response to the needs of remittance-related financial services, the Ministry of Overseas Indian Affairs (MOIA) has introduced a special social security scheme named "Mahatma Gandhi Pravasi Suraksha Yojana" for overseas Indian workers. This scheme helps them to save for their pension through NPS-Lite (National Pension Scheme); to save for their return and resettlement; and to obtain life insurance cover free of charge ${ }^{36}$.

Other government initiatives that cover some aspects of education or inclusion of relevance to the financial wellbeing of migrants include:

- a new migration policy including a mandatory pre-departure orientation course for all migrants

33 Information taken from Session D presentations at Citi-FT Financial Education Summit 2013: https://www.eiseverywhere.com/file uploads/7b0ad84c66fdc57fcd8e15bbadb78bc1 DayOne-5PeterWong-Plenary-PeterWong-VisaChinaFLprogram-forFT.pdf accessed 4 April 2014; see also http://www.theinno.org/; http://www.cfdfe.cn/html/Home/report/1324-1.htm and http://www.practicalmoneyskills.com/about/cfdfe_china_0713.php

34 Unicef report estimates from 2001 indicating that almost $30 \%$ of the population of India were internal migrants http://www.unesco.org/new/fileadmin/MULTIMEDIA/FIELD/New_Delhi/pdf/imiilatest.pdf

35 Information provided through OECD/INFE survey of members in 2013 and drawn from http://indiagovernance.gov.in/bestpractices.php?id=430

36 Press Information Bureau - Government of India, http://pib.nic.in/newsite/efeatures.aspx?relid=85733. This scheme operates in countries where emigration checks are not required by the MOIA. For more information on emigration checks, see www.immihelp.com 
- a Gulf-returnee entrepreneurship promotion programme designed to promote investment in India which would provide opportunities to those who have returned;

- a campaign to increase awareness of the availability of programmes to improve skills;

- collaboration between Indian embassies and various local media to popularise formal and affordable financial services available to migrant Indian workers ${ }^{37}$.

There are also various national and international programmes designed to support Indian migrants, but these do not explicitly target financial literacy or financial inclusion. Examples include the Indian Council of Overseas Employment (ICOE) 2-year project on the "Empowerment of Women Migrant Workers in the Gulf" in collaboration with the UN Women and country manuals circulated by the Indian Government to migrant workers in Bahrain, Kuwait, Malaysia, Oman, Qatar, Saudi Arabia, and $\mathrm{UAE}^{38}$.

In addition to policy responses from India, independent research has looked at financial education for Indian migrants. A robust evaluation has been undertaken of a motivational financial education seminar for male Indian migrants in Qatar ${ }^{39}$, delivered by the head of the Pravasi Bandhu Welfare Trust, an organisation that has been working with migrants to improve their financial behaviour for over 10 years (Seshan and Yang, 2014). The programme was specifically designed to change behaviour, and the evaluation looked at the impact on financial practices, savings goals, joint decisionmaking, savings and remittances over a year later. The findings show that the short seminar increased the proportion of migrants making joint financial decisions with their wives. There were no effects on average on the amount saved or remitted, but after the seminar, migrants with low savings increased their savings. The results also showed that wives of migrants who had been invited to the seminar were more likely to seek financial education for themselves in India, suggesting an important role for Indian providers if such a programme continues.

\section{Indonesia: targeting financial inclusion and financial education across the population}

Around 1\% of Indonesian's were migrants in 2010 and estimates from 2009 indicate that they remitted USD 6.8 billion (Stock of emigrants, 2.5 million, Ratha et al, 2011). In addition to the 600,000 officially registered migrant workers going abroad each year it is recognised that there are a large number of unrecorded migrants working oversees.

In light of the Indonesian governments stated concern with poverty alleviation and the potential of migrant workers to play a role in the achievement of this goal, it is clear that there is a need to improve access for members of this group to financial services and physical infrastructure. Bank Indonesia has taken a lead through its Indonesia Banking Architecture (API), launched 9 January 2004 , followed by banking public education in 2007. A blue print on public education in banking was also created in 2007. The education provided also specifically covers awareness building of rural

37 Government of India - http://www.moia.gov.in/writereaddata/pdf/deloitte_study.pdf

38 http://moia.gov.in/services.aspx?id1=75\&id=m1\&idp=75\&mainid=73 , Government of India, Circulation of Country Manuals for Emigrant Workers, http://moia.gov.in/services.aspx?id1=366\&idp=366\&mainid=73 See also discussion on victimisation of female migrants http://www.academia.edu/990545/Victimization_of_Female_Indian_Migrant_Workers_in_Gulf_Countries

39 In 2010, immigrants made up 87\% of the population of Qatar, whilst 1\% of Qataris lived abroad (Ratha et al, 2011). 
banks and the secure use of non-cash payment instruments, both of which could benefit migrants and their families.

Specific financial education has been provided to migrant workers since 2008 by public bodies, and since 2011 this has incorporated entrepreneurship. Financial education messages about banks provided as part of the 2008 national campaign under this blue print included the three simple rules of benefit to migrants and others: "Whatever the products, remember to 1) ensure the benefits, 2) understand the risks, and 3) consider the cost".

Indonesia has a national strategy for financial education which was launched under the National Strategy for Financial Inclusion in 2012. Financial education is one pillar of the inclusion strategy, which targets the low-income poor, the working poor, including MMSEs, migrant workers and those in remote areas, and the non-poor. It focuses on increasing the level of knowledge of financial product and services, improving information on consumer protection and providing information on financial management. In 2013, the Blueprint of National Strategy on Financial Literacy was also launched by the President of the Republic of Indonesia to ensure that all efforts to increase financial literacy are structured and systematic. This blueprint will guide the authorities in the financial sector, financial institutions, and other stakeholders.

As part of the strategy, the Indonesia Financial Services Authority (OJK), the Central Bank, the Ministry of Manpower and Transmigration, the National Authority for the Placement and Protection of Indonesian Overseas Workers (BNP2TKI), financial institutions and other stakeholders are working hand-in-hand to provide financial education to migrant workers and their families - including knowledge of savings, remittances, credit payments and small business loans. Migrants are then given training to practice applying this knowledge. OJK reports that feedback from migrants receiving this training shows that the content was well received and could be easily understood and implemented. However, they also note that lack of resources for trainers limits the extent to which this approach can be scaled up.

In addition to the national strategy, the Indonesian Banking Architecture has served as a platform for customer education and financial consumer protection since 2004 (G20/OECD, 2013) $)^{40}$. A blue print on public education in banking was created in 2007 and is still being followed. This identifies target groups and delivery methods for communicating with the public. It allows for financial education provision to a group described as 'others' that fall outside the main target groups and could incorporate migrants or their families. The education provided also specifically covers awareness building of rural banks and the secure use of non-cash payment instruments, both of which could benefit migrants and their families. Furthermore, financial education has been provided to migrant workers since 2008 by public bodies, and since 2011 this has incorporated entrepreneurship.

\section{Identifying the needs of migrant workers}

The OJK stresses that financial education is a complement to consumer protection and financial inclusion initiatives. Indonesia has recognised that one of the main issues for migrants is a strong disconnect between available financial products and the needs of the migrants; this is due both to a lack of supply of suitable products and a lack of awareness on the part of the migrants themselves. Migrants are also recognised as an easy target for abuse due to their lack of knowledge. The OJK also recognises that it is beneficial to design financial education materials and programmes for migrants and their families according to the different stages of the migration process, pre-departure; during

40 Information in this section is also drawn from presentations at various OECD/INFE conferences since 2010 . 
migration and post-migration. They currently focus primarily on pre-migration and during migration. In pre-departure stage education programmes, financial education covers financial planning, basic financial products and services, such as savings and credit. During migration, there is a focus on remittances.

\section{External evaluation}

An independent, robust evaluation of financial education for migrant workers from Indonesia and their families has also been undertaken, as discussed in Section I (Doi et al, 2012). This highlighted the benefit of providing education to both the sender and receiver of remittances before the migrant left Indonesia (treating planned migration as a teachable moment), with a subsequent large increase in savings and a decrease in reliance on credit. This was apparently caused - not by an increase in remittances, but - through better money management. It is interesting to note that in contrast, when migrant workers received the training but their family did not, the impacts on knowledge, behaviour and outcomes were insignificant, illustrating the importance of including family members.

\section{Mexico: providing financial education at home and abroad}

Over 10 percent of the Mexican population lived overseas as migrants in 2010 (10.7\%, stock of emigrants: 11.9 million; Ratha et al, 2011) and top destination countries include the United States, Canada, Spain, Bolivia, and Germany. Mexico-United States is reported to be the largest migration corridor in the world, accounting for 11.6 million migrants in 2010 (98\% of Mexicans living abroad reside in the United States). Almost a third of all Mexican immigrants currently in the United States arrived in 2000 or later (Laureen Laglagaron Migration Policy Institute, 2010).

Mexican immigrants are a vulnerable group within the US for several reasons. They have considerably lower than average levels of education than other migrant groups, and support relatively large families in the US (an average household headed by a Mexican born immigrant is almost 5 people) and are likely to have the lowest-paying jobs in low-income sectors (Brick et al, 2011).

Furthermore, in the US, over half (53\%) of Mexican immigrant households do not have bank accounts. This rate of financial exclusion exceeds that of other foreign born immigrants in the country (37\% of other Latin American, 20\% of Asian and 17\% of European households are financially excluded; Barcellos et al, 2012). Mexicans are also less likely to participate in formal retirement savings programs or to have credit cards, and have lower levels of financial literacy. Several barriers limit Mexican's access to financial services in the US including limited English proficiency, lack of understanding of the US financial system and cultural differences and levels of confidence in the use of financial services (Institute for Latino Studies, 2008).

\section{Mexico increasing financial inclusion and supporting potential migrants and their families}

Mexico sees financial education as a fundamental part of its strategy to increase financial inclusion and an important complement to financial consumer protection (G20/OECD, 2013). Its current National Development Plan (2013-2018), includes as one of its objectives an increase in the responsible access to financial services, whilst the National Development Financing Program (20132018) aims to develop greater financial capabilities to make better use of financial products and services and to foster financial consumer protection; including promoting financial education for new entrants into the formal system.

There are two co-ordination entities chaired by the Ministry of Finance and Public Credit: a National Council for Financial Inclusion coordinates the planning, formulating and execution of the 
national financial inclusion policy whilst the Committee for Financial Education coordinates the financial education activities and programmes of its members. The Institute for Mexicans Abroad (IME; see below for further information) and BANSEFI (Banco del Ahorro Nacional y Sevicios Financieors, S.N.C., one of the national development banks operating in Mexico, focused on promoting financial inclusion) are members of this committee, indicating recognition of the relevance of financial inclusion for migrants and their families as well as for financial development.

BANSEFI is also one of the institutions that provide information and financial education courses and materials to consumers and offer training for financial education trainers. These are accessible in physical locations or through its webpage and are designed for the general public, including potential migrants and their families. The courses and material cover financial planning, savings, credit, insurance, financial services and remittances. The remittances section is composed of seven modules dealing with the different types of remittances, how to choose the financial product to send and receive remittances, how to plan the use of remittances and how to save and invest the money received, as well as on the services provided by the IME in the US. Each year BANSEFI coordinates with IME to provide printed financial education materials to consulates participating in the Annual Financial Education Week events and has presence in consulates providing financial education for migrants.

\section{Mexican support for migrants within the US}

The Mexican government has taken initiatives to improve migrants' financial literacy as well as health care, education, workforce development, English language acquisition and leadership in the United States, recognising that social and financial integration in the US is important for Mexican migrant workers (Laureen Laglagaron Migration Policy Institute, 2010). Of particular note is the Institute for Mexicans Abroad (IME), created in 2003 from a previous programme developed by the Mexican Foreign Ministry.

The IME has an advisory council made of representatives of Mexican communities in other countries, and structured into nine commissions including education, legal affairs and economic and business affairs. The IME has partnered with the Inter-American Development Bank (IDB), a multilateral lending institution, to provide financial education to migrants as well as to their families living in Mexico.

The Direction of Economic Affairs within the IME provides information to migrants on formal banking, depositing, remittance price comparison, investment and entrepreneurship and creates videos and other educational material that emphasise the importance of using the formal banking system. This information is available through mass media, on-site training, distance training, workshop and textbooks distributed to migrants and their families. The services are provided at the consulate offices, educational institutions, community centres, health centres and libraries with the partner organisations. Although the number of beneficiaries reached has not been reported, 50 consulates have participated in annual events with financial education themes (Hall, 2010).

Among other programmes, every March the Mexican Consular Network in the US and Canada, with the guidance of IME, organises the Financial Education Week for the migrant community. In 2014 this reached about 80 thousand Mexican nationals with educational programmes and services covering many topics including financial inclusion, productive investment with remittances and saving for retirement. For 2015, the goal will be to reach 100 thousand Mexican nationals and have all 56 Consulates (in US and Canada) participate. Relevant topics as entrepreneurship and innovation will also be introduced. 
In addition, the IME and Mexico's consular network have sought agreements with banks to accept the matricula consular ${ }^{41}$ as a form of identification to open a bank account. In exchange, banks are authorised to provide banking information inside consulate offices, including information on safe remittance methods and basic financial literacy (Laureen Laglagaron Migration Policy Institute, 2010). IME also co-ordinates a network of collaboration agreements between banks and $80 \%$ of Mexican Consulates to have a banking representative present at their consular offices, to speak to the public about banking services and their benefits.

\section{The Philippines: migrants explicitly included in National Strategy for financial education}

Almost one in 20 of the population of the Philippines lived overseas as a migrant in 2010 (4.6\%, stock of migrants: 4.3 million, Ratha et al, 2011). Data for 2012 indicates that 2.2 million Filipinos aged 15 and over worked abroad at some point between April and September of that year (Philippine Statistics Authority, 2013), of which just over half were male (52\%). A third of these workers were unskilled, whilst $12 \%$ were professionals. The primary receiving countries during this period were Saudi Arabia, United Arab Emirates, Singapore and Qatar. These migrant workers sent home 165.6 billion pesos in the 6 month period; primarily through banks $(71 \%)^{42}$.

The Philippines recognises the importance of remittances to the economy, and is working hard to support the flow of remittances and to mobilise the receipts to fund productive activities ${ }^{43}$. In 2004, the Asian Development Bank provided the Philippines with Technical Assistance on ways of enhancing the efficiency of overseas workers remittances, which included mention of the importance of high quality, pre-departure financial literacy programmes and suggested providing financial education at the community level (ADBI, 2004). Of all the countries receiving substantial remittances payments it now appears to have progressed furthest in its national efforts to support migrant workers through financial education. It has a national programme through its National Strategy on Financial Education that is aimed specifically at migrant workers at home and overseas:
“...In line with its ongoing advocacy programs, the Bangko Sentral is undertaking a nationwide financial literacy campaign to help channel remittances to development activities and to promote a culture of saving among OFWs [overseas Filipino workers] and their families. The financial literacy program emphasizes the importance of savings and introduces the participants to alternative opportunities for their remittances, such as placements in financial instruments and investments in business ventures." Governor Amando M. Tetangco, Jr. Bangko Sentral Ng Pilipinas (BSP).

This Financial Learning Campaign for Overseas Filipinos is part of the BSP's drive to promote a culture of saving among migrants and their families and to encourage the channelling of these savings into productive investments. In response to the latest research it targets both the migrant worker and their family. In addition to focusing on productive investments, it emphasises the importance of setting aside funds specifically for retirement purposes. The topics covered therefore aim to provide target participants with brief guidelines on retirement planning, different types of savings and investment instruments, and tips on remittances, savings and investment protection.

41 The Matrícula Consular de Alta Seguridad (MCAS) (Consular Identification Card) is an identification card issued by the Government of Mexico through its consulate offices to Mexican nationals residing outside of Mexico.

42 At current exchange rates (April 2014) this is approximately USD 3.7 billion.

43 Presentation from OECD-BSP Asian Seminar on Financial Inclusion 2012: Bangko Sentral ng Pilipinas, accessed 4 April 2014 http://www.oecd.org/daf/fin/financialeducation/4\%20RCGonzaga_OECD\%20Session\%204 final-REV3sep.pdf 
The campaign uses a variety of delivery channels including video, public speakers and discussions to prepare staff and sessions for partner agencies. It is a cross-government exercise, with inputs from various departments, including the Department for Trade and Industry and the Department of Agriculture as well as the Social Security System and the Philippine Stock Exchange. It also benefits from various funding streams, including, for example, a USD 220,000 pledge from the Western Union Foundation in 2013 to support a financial literacy programme led jointly with the United Nations Development Program ${ }^{44}$.

The programmes also receive sponsorship from the Philippines Embassy and Consulate General in several countries. Between 2006 and 2012, 72 campaigns were conducted across the Philippines and in countries and economies with high concentrations of Filipino migrants: Italy; the UK; Korea; Singapore; Hong Kong, China; Qatar; Bahrain and Saudi Arabia ${ }^{45}$.

The BSP collects quarterly data on the expenditure of emigrants in order to track changes and evaluate the Financial Learning Campaign. This shows a large increase in savings behaviour, with 7.2\% of Filipinos overseas saving in Q1 2007 rising to 44.5\% in Q2 $2012^{46}$.

The BSP is also supporting migrants wanting to make remittances through a number of practical steps including: making sure remittance charges are clearly displayed; making information about remittance services fees and rates available through an online portal; connecting various ATM networks, and approving new remittance transfer technologies.

The Philippine Overseas Workers Welfare Administration (OWWA, a government agency attached to the Department of Labour and Employment) requires potential migrant workers to complete an eight hour pre-departure orientation seminar, which includes financial literacy and offers a reintegration programme for returning workers. Returning workers are also catered for by the Philippine Overseas Employment Administration which includes access to credit and associated financial literacy training.

There are various other initiatives designed to provide financial education and related support to Filipino migrants and their families. A survey conducted by the CFO identified 29 organisations targeting migrants and their families with financial literacy training, including banks, civil society associations and insurance companies (Manila Bulletin, 2013). These often focus on developing financial independence, including in some cases helping migrant workers to consider the option of breaking away from the migration cycle (Abenoja and Salva, 2011).

\footnotetext{
44 http://www.ph.undp.org/content/philippines/en/home/presscenter/pressreleases/2013/10/18/undp-and-cfolead-program-aimed-at-remittance-beneficiaries-with-scalable-modules-for-all-filipinos.html

45 See the section below 'B. Host countries' for more information on this.

46 Presentation from OECD-BSP Asian Seminar on Financial Inclusion 2012: Bangko Sentral ng Pilipinas
} 


\section{B. Host countries}

\section{Australia: addressing the needs of arrivals from across the globe}

Australia released a National Financial Literacy Strategy in 2011, to provide a framework to improve the financial literacy of the whole population. The strategy is co-ordinated by the Australian Securities and Investments Commission (ASIC). It does not explicitly mention migrants, but the website used to disseminate much of the educational content (MoneySmart ${ }^{47}$ ) has various resources that are specifically designed for this target group. A Money Management Kit has been designed to help settlement workers deliver education about money management issues as part of the onshore orientation framework. The Australian Department of Immigration and Citizenship has endorsed the kit and encourages all settlement workers to use it to help their clients understand how to manage their money in Australia. The kit contains fact sheets, audio content and videos in 16 different languages ${ }^{48}$ and covers topics such as household budgets, saving money, paying bills, contracts, banking, credit, debt, insurance and working in Australia.

Other publications and media content for migrants can also be accessed through the website. Basic information, briefly explaining the role of ASIC and MoneySmart, linking to calculators (in English) and explain how to make complaints is available in 26 community languages. The page also has links to translated versions of several of ASIC's fact sheets on topics such as borrowing money, paying debts, consumer leases and car loans. Elsewhere on the website migrants and their families can find out about different ways to transfer money, how to compare costs and exchange rates, how to pay lower fees, and how to complain if there is a problem.

\section{Canada: multi-agency efforts on financial education for migrants}

Canada has identified financial literacy as an important policy priority and undertaken a detailed research and consultation exercise in preparation for its national strategy. Newcomers to Canada are identified as a specific target group for the strategy, and a report on Financial Literacy to the Minister of Finance in 2010 recommended that the government should provide relevant financial information and education as part of the immigration process (Canadian Task Force on Financial Literacy, 2010; G20/OECD, 2013). However, financial education is not included in the Immigrant Settlement and Adaptation Program and the Language Instruction for Newcomers to Canada Program.

In Canada, several organisations such as local governments, non-profit institutions and financial institutions provide financial education programmes for migrants (SEDI, 2008). The topics of the programmes include budgeting, credit cards and credit bureaus, fraud, identity theft, consumer rights, income taxes, saving and investment, financial planning and government subsidies ${ }^{49}$. Such programmes include an initiative in Ontario funded by the Ministry of Economic Development and Trade which has worked with over 750 migrant youth, providing both financial literacy and entrepreneurship skills ${ }^{50}$. In addition, many banks in Canada provide free, non-commercial financial literacy seminars for community groups as well as consumer information web pages to help to overcome cultural differences and language challenges (Canadian Bankers Association, 2010).

\footnotetext{
$47 \quad$ www.moneysmart.gov.au

48 Arabic, Assyrian, Burmese, Chin Hakka, Dari, Dinka, Farsi, Hazaragi, Karen, Kirundi, Nepalese, Nuer, Sudanese Arabic, Swahili and Tamil.

49 New York Community House, Financial Literacy, http://www.nych.ca/programs/skills-leadership/financialliteracyl, accessed on 20/12/2012

50 http://www.theccfl.ca/Services/Training-Capacity-Building.aspx
} 


\section{Saudi Arabia: migrants receiving support from their home countries}

Whilst there are many initiatives in Saudi Arabia that seek to raise awareness of different aspects of financial services (such as lending transparency and financial security), the Saudi Arabian government does not currently have programmes designed for migrant workers. However financial education is arguably becoming increasingly important for migrants working in the country, as the government is moving toward a new policy which will make migrants pay health insurance and impose a direct tax on migrant workers (Thimothy and Sasikumar, 2012).

The current lack of financial education initiatives may change in the near future. Saudi Arabia is currently in the process of preparing a national strategy for financial education (G20/OECD, 2013). The intention is that this will be targeted at groups in need, including SMEs, youth and women and will give priority to improving living standards and quality of life. It will build on international guidance, taking into account local culture and Islamic finance practices. The topics to be covered include practical issues that will be of benefit to migrants such as budget management, saving and investing, as well as taxation and there will be more customised education for various groups including users of microfinance. However, whilst disadvantaged persons and those on a low income are mentioned as potential target groups, migrants are not and there does not appear to be any specific provision for remittance senders.

There are some financial literacy programmes available to migrant workers in Saudi Arabia through the efforts of home countries. For example, in 2012, the Philippine Embassy in coordination with the Philippine Labour Office in Riyadh conducted the first seminar on financial literacy which focused on how to save earnings and build personal wealth.

\section{The United Kingdom: not-for-profit institutions providing financial education to migrant groups}

The UK government began its first National Strategy for Financial Capability in 2003 and exceeded its target of reaching 10 million people (G20/OECD, 2013). In 2010 it launched a new service with responsibility for financial capability, which was renamed The Money Advice Service (MAS) in 2011. This is an independent service designed around the lessons of behavioural economics to give a range of financial advice, including debt counselling and a financial health check. It uses life events and specific queries such as those relating to changes in tax or benefits to trigger broader interest in the service. Although migrants are not specifically targeted by MAS it aims to provide impartial advice to everyone, and includes relevant advice on financial products including bank accounts and remittance services, including how to check whether a firm is authorised. Materials are only available in English and Welsh, however, potentially limiting their use to new migrants with limited language skills.

MAS is in the process of developing a new strategy for financial capability. This will build on the earlier strategy and on research undertaken since to further understand the needs and behaviour of UK residents. It is will incorporate outcome based evaluation into the design, using a common framework.

Several non-profit organisations in the UK provide financial education programmes for vulnerable groups including migrants and their families - who typically have lower financial literacy than native born residents (Taylor, 2009). Citizens Advice Bureaux (CABx), which deliver advice services from over 3,500 community locations in England and Wales run by 382 individual charities, have been helping migrants in accessing financial education ${ }^{51}$. Citizens Advice Belfast have researched the challenges that migrants face including difficulties in opening bank accounts and

51 Citizens Advice, http://www.citizensadvice.org.uk/ 
transferring money home, accessing credit, and having access to a debit card to book travel tickets (Citizens Advice Belfast, 2010). They have developed an information session which covers banking and banking services, credit facilities, debt management and income maximisation, and is delivered via Polish Chinese and Indian community centres and associations.

A 2009 mapping of financial education provision in Northern Ireland found that two consumer organisations were actively working with migrants, Advice NI and the Consumer Council (The Consumer Council, 2009). Both organisations are still active: Advice NI currently provides information online in seven languages ${ }^{52}$, whilst the Consumer Council disseminates English language materials such as home budget planners online and through voluntary and community organisations ${ }^{53}$.

\section{The United States: focusing on various vulnerable groups}

The United States government launched a National Strategy for Financial Literacy in 2006 which was revised in 2011; in 2012 the Financial Literacy and Education Commission was established to lead the strategy and coordinate resources and activities among member agencies. Although migrants are not specifically targeted in the National Strategy, the government notes the importance of targeting low- to moderate-income, minority, unbanked, and underserved communities ${ }^{54}$.

A variety of providers including federal governments, cities, community-based organisations, and immigrant service organisations have provided financial education programmes for migrants. According to a survey of federal financial and economic literacy education programmes in 2009, 26 federal governments' programmes include migrants and/or their families as the target audience either explicitly or by incorporating financially vulnerable populations such as the less-educated, lower income and Hispanics (Hung et al, 2009; see also Table 1 for the subset that explicitly mention migrants). For example, the National Resource Center on Women and Retirement Planning ${ }^{55}$ focuses on hard-to-reach women including migrants by providing culturally relevant education and booklets such as "Financial Steps for Caregivers" and "What Women Need to Know About Money and Retirement" available in various languages.

A new randomised control trial of financial education aimed at Hispanic migrants in the US ${ }^{56}$ has tested the FDIC's online Money Smart Curriculum ${ }^{57}$, and a revised version of the curriculum with an additional Question and Answers section designed to take into account the particular needs of immigrants (Barcellos et al, 2014). The researchers found that either version of the programme led to an increase in knowledge but a 6 month follow up survey indicated that this knowledge was not retained. The programme did not appear to change behavioural intentions. This suggests that such interventions would need to occur at the point at which the knowledge is required, and that longer, or different programmes would be necessary to create lasting effects.

\footnotetext{
$52 \quad$ www.adviceni.net

53 www.consumercouncil.org.uk

54 The United States - National Strategy for Financial Literacy 2011

55 http://www.aoa.gov/AoARoot/Press_Room/Products_Materials/fact/pdf/Women_Retirement_Planning.pdf

56 The migrants in the study are part of a national research panel, which provides internet connection if necessary.

57 The programme is available in English and Spanish http://www.fdic.gov/consumers/consumer/moneysmart/index.html
} 
A project from the Inter-American Dialogue investigated the effects of providing specially designed financial education to around 100 migrants in the US through existing institutions with a strong engagement with Latino immigrants (Orozco et al, 2010). The education, which was delivered in classroom settings and one-to-one, had a particular focus on increasing financial inclusion, providing information on basic financial issues and disseminating other materials. The researchers note that the success of the financial education projects appeared to depend on the quality of the instructor and the environment that the education was delivered in - with some space for semi-private discussion being an important component.

The Lutheran Immigration and Refugee Service has also been active in the provision and review of financial literacy for recent migrants living in the US, through its RefugeeWorks programme (Lutheran Immigration and Refugee Service, 2012; the report also contains several valuable casestudies of practical financial education initiatives). This programme sought to identify the needs of newcomers, the usefulness of existing resources and the changes that are necessary to make financial literacy resources responsive to the diversity of migrants' experiences. It found that financial education for migrants needs to:

- be culturally sensitive;

- tackle issues of trust and access;

- help migrants with practical matters such as transferring money abroad, living within ones means and avoiding scams and high-cost financial services such as logbook loan companies; and

- $\quad$ address a lack of language skills.

It also noted the difficulty faced trying to find suitably well-informed trainers (which is a common problem for financial education programmes) and the disadvantages of using trainers who do not have in-depth knowledge.

There are a number of other organisations, including remittance providers, who offer financial education to migrants in the US (Durana, 2010). These focus on topics such as remittance payments, responsible borrowing, saving, and the use of financial products. The US Committee for Refugees and Immigrants (with support from the Citi Foundation) has also developed a financial literacy curriculum in 6 languages to meet the needs of diverse migrant populations and is designed to be culturally sensitive. This covers, credit, electronic banking and the use of banks and is made available to qualified community trainers ${ }^{58}$.

There is also interest in understanding the remittance behaviour of migrant workers in the US. This has recently been addressed through quantitative research undertaken by The University of Chile (Ashraf et al, 2011) and the Multilateral Investment Fund of the Inter-American Development Bank (Orozco and Jewers, 2014). Ashraf and colleagues undertake a random control trial on El Salvadorian migrants and their families, and find that families and migrants accumulate more money in savings when the migrants are able to monitor and control the savings accounts in El Salvador; migrants with a pre-identified demand for control who were provided with the opportunity to control the savings accounts in El Salvador also increased their monthly earnings by an average of 505 USD, apparently to fund their US savings accounts. Orozco and Jewers' work recommends ways of harnessing opportunities for better financial inclusion for migrants in the US, including through the provision of financial education.

58 http://www.refugees.org/resources/for-refugees--immigrants/financial-literacy.html 
Table 1. US programmes that include migrants and/or their families

\begin{tabular}{|c|c|c|}
\hline Agency & Programme & Target audience \\
\hline $\begin{array}{l}\text { Federal Reserve Board of } \\
\text { Governors }\end{array}$ & Program & $\begin{array}{l}\text { Immigrants and other targeted } \\
\text { population }\end{array}$ \\
\hline \multirow{2}{*}{$\begin{array}{l}\text { Federal Trade } \\
\text { Commission }\end{array}$} & ID theft & $\begin{array}{l}\text { Immigrants and other targeted } \\
\text { population }\end{array}$ \\
\hline & Hurricane Recovery & $\begin{array}{l}\text { Immigrants and other targeted } \\
\text { population }\end{array}$ \\
\hline \multirow{3}{*}{$\begin{array}{l}\text { U.S. Department of } \\
\text { Health and Human } \\
\text { Services }\end{array}$} & $\begin{array}{l}\text { National Education and Resource } \\
\text { Center on Women and Retirement } \\
\text { Planning }\end{array}$ & $\begin{array}{l}\text { Hard-to-reach woman including } \\
\text { immigrant women }\end{array}$ \\
\hline & $\begin{array}{l}\text { Pension Counselling and Information } \\
\text { Program }\end{array}$ & $\begin{array}{l}\text { Underserved and hard-to-reach } \\
\text { populations including immigrants }\end{array}$ \\
\hline & $\begin{array}{l}\text { Medicare Improvements for Patients } \\
\text { and Providers Act }\end{array}$ & Includes Medicare eligible immigrants \\
\hline $\begin{array}{l}\text { Office of the Comptroller } \\
\text { of the Currency (OCC) }\end{array}$ & Minority Media Campaign & $\begin{array}{l}\text { Minority communities including } \\
\text { immigrants }\end{array}$ \\
\hline $\begin{array}{l}\text { U.S. Department of } \\
\text { Agriculture }\end{array}$ & Financial Security Program & $\begin{array}{l}\text { Financially vulnerable populations } \\
\text { including immigrants }\end{array}$ \\
\hline
\end{tabular}

Source Hung et al, 2009 


\section{CONCLUSIONS AND OUTLOOK}

Migrant workers have an important role to play in supporting their families back home, whether home is in a different town, state or country. Their remittances put vital money into their home economy /country and ultimately help to support economic growth. In turn, through the use of formal financial products, this flow of money can support investment and financial stability. In order to maximise the benefits of their income, migrants and their families need access to appropriate financial products and services, and the knowledge and skills to be able to manage their finances and make financial decisions. This paper highlights the potential role of financial education for migrants and their families, both as a demand-side solution to financial inclusion, and as a means of improving financial wellbeing. Country case studies help to illustrate the growth in policy awareness and action on this important topic. However, it is clear from this preliminary study that whilst important work is being done internationally to create financial education toolkits for those working with migrants, migrants' access to financial education is variable. Holistic approaches to reaching migrants and their families with financial education and financial inclusion initiatives are rare. In addition, countries' goals and policies on migration and migrants are not necessarily fully aligned. There appear to be several reasons for this, of which the following stand out:

- The term migrant encompasses many different groups including internal migrants as well as both legal and illegal immigrants. There are political sensitivities in some countries that can make it difficult to allocate resources to support migrants, particularly if the benefit is accrued in other countries.

- In most countries, national financial education initiatives do not identify either migrants or their families as important target groups for financial education or discuss the specific financial education needs of such groups. Despite this, there may be an expectation that existing financial education and/or financial inclusion efforts effectively target migrants by default. Yet financial education initiatives that are targeted at all adults may not encompass the needs of migrants and their families. For example, they are unlikely to cover low-cost, secure remittance channels or discuss the issue of cross-border banking and account management. Tailored financial education curricula may be needed for this target group in order to fully meet their specific needs and reduce the demand-side barriers that can prevent optimal use of migrant earnings.

- Migration corridors provide some indication of the typical host and home countries, but the reality is much more complex. A strategy designed to support new-comers needs to provide information in multiple languages and keep in mind the range of backgrounds that these migrants come from. Equivalently, emigrants can seek work in many different countries, each with its own financial market and cultural norms, making it difficult to address country specificities in any pre-migration programme. In both home and host countries programmes need to be flexible, as both financial markets and migration patterns change over time.

- Countries that benefit the most from migrant remittances are also typically emerging economies with less well developed financial services, making cross-border financial inclusion initiatives including financial sector deepening vital but complex. 
Countries that do recognise the importance of supporting migrants and their families are at different stages in terms of planning and implementing a practical solution. In particular, some host countries are making efforts to support migrants and their families at home and in their host countries, but this is far from universal. Elsewhere, NGOs and other stakeholders are also trying to fill the gaps in provision, and are providing a valuable contribution in many countries, albeit on an ad hoc basis. The findings reported in this paper suggest that:

- Both internal and international migrants and their families need to be recognised as specific target groups for financial education and financial inclusion initiatives. In addition to needing the same financial education and products as the general population they also need products, knowledge and skills that are specific to their situation.

- Financial education activities need to occur on an international level or across key migrant corridors given the global phenomenon of migration and remittances. Countries should be encouraged to work together to support migrants and their families; maximising access to the target group, and drawing on materials and resources in national languages that recognise and respect cultural, social and religious differences. This co-ordination must be designed to reflect ongoing supply-side efforts to increase financial inclusion, which will hopefully result in a step change in terms of financial product choices for migrants and other vulnerable groups in the near future.

- To some extent, the needs of migrants and their families will vary according to their sociodemographic characteristics, whether they are internal migrants, and if not, their home and host country, as well as supply side factors including availability of financial products and services. Subgroups of migrants may therefore require different levels of intervention and support to become financially literate and included. The needs of each group should be identified and addressed.

- Family members are as important as migrant workers themselves. Some migrants arrive in the host country or region with family. These family members should be included in financial education initiatives - a whole family approach could help to strengthen the message and promote a unified set of behaviours within the household. Families receiving remittance payments should also be included. They are responsible for making effective use of the money received, and as such they are key to harnessing remittances for maximum benefit at a national level.

- Any co-ordinated approach to supporting migrants that combines the provision of essential healthcare, education and guidance to new migrants should include financial education and information to promote financial inclusion in the host and home country. It is important that these pay sufficient attention to the financial education needs of migrants in addition to providing information on other subjects.

- In some countries the size of the migrant population suggests the need for widespread approaches targeting large numbers of individuals through migrant newspapers, social media, employers and schools using the language of the migrant wherever possible. Elsewhere, stakeholders working on financial education or financial inclusion initiatives should be sensitised to the financial education needs of migrants and their families.

Product design and financial consumer protection initiatives are beyond the scope of this paper, but the findings certainly indicate that there could be additional benefits to migrants and countries with large migrant populations from harmonising financial consumer protection frameworks and developing international good practices on basic product design for products such as remittances and simple transaction accounts. 


\section{ANNEX 1. THE MILLENNIUM DEVELOPMENT GOALS}

Goal 1: Eradicate extreme poverty and hunger; (targets of particular relevance to migrants include 'Halve, between 1990 and 2015, the proportion of people whose income is less than $\$ 1.25$ a day', and 'Achieve full and productive employment and decent work for all, including women and young people';

Goal 2: Achieve universal primary education;

Goal 3: Promote gender equality and empower women;

Goal 4: Reduce child mortality;

Goal 5: Improve maternal health;

Goal 6: Combat HIV/AIDS, malaria and other diseases;

Goal 7: Ensure environmental sustainability;

Goal 8: Develop a global partnership for development. (Pertinent targets include 'Develop further an open, rule-based, predictable, non-discriminatory trading and financial system', 'Address the special needs of least developed countries' and 'In cooperation with the private sector, make available benefits of new technologies, especially information and communications'. 


\section{REFERENCES}

Abenoja, Z. And Salva, A. (2011). Presentation

http://d2dinvestment.cfo.gov.ph/files/Global_Summit/2011/SALVA_Financial_Education_Prog rams.pdf

ADBI (2004). Enhancing the Efficiency of Overseas Workers Remittances. Asian Development Bank Institute. Technical Assistance, Final Report. MFG-EN-Paper-Enhancing-the-Efficiency-ofOverseas-Workers-Remittances-2004.pdf

Afram, G. G. (2012). The Remittance Market in India: Opportunities, Challenges, and Policy Options, The World Bank https://openknowledge.worldbank.org/handle/10986/2228

Agunias, D.R. and K. Newlan, (2012). Developing a Road Map for Engaging Diasporas in Development, Chapter 6: Remittances: Making Private Money Work for the Common Good http://www.migrationpolicy.org/pubs/thediasporahandbook.pdf

Atkinson, A and F. Messy (2013). Promoting Financial Inclusion through Financial Education: OECD/INFE Evidence, Policies and Practice. OECD Working Papers on Finance, Insurance and Private Pensions, No.34, OECD Publishing. http://dx.doi.org/10.1787/5k3xz6m88smp-en

Azad, A. K. (2005). Migrant Workers' Remittances: A source of Finance for Micro-Enterprise Development in Bangladesh? in Remittances. Development Impact and Future Prospects (eds S. M. Maimbo and D. Ratha).The International Bank for Reconstruction and Development/The World Bank, Washington

Bachtiar, P. P. (2011). The Governance of Indonesian Overseas Employment in the Context of Decentralization.

Barcellos, S. H., L. S. Carvalho, J. P. Smith, and J. K. Yoong (2014). Financial Education Interventions Targeting Immigrant Populations: Results from a Randomized Control Trial in the United States (Working Paper, USC). http://works.bepress.com/silvia_barcellos/11

Barcellos, S. H., J. P. Smith, J. K. Yoong and L. Carvalho, (2012). Barriers to Immigrant Use of Financial Services: The role of language skills, U.S. experience, and return migration expectations http://www.rand.org/pubs/working_papers/WR923.html

Brick, K. et al (2011). Mexican and Central American Immigrants in the United States http://www.migrationpolicy.org/pubs/MexCentAmimmigrants.pdf

Canadian Bankers Association, (2010). Banks in Canada help new comers find their financial footing, http://www.cba.ca/en/media-room/65-news-releases/547-banks-in-canada-help-newcomersfind-their-financial-footing, accessed on 20/12/2012

Canadian Task Force on Financial Literacy, (2010). Canadians and their money - Building a brighter financial future, Report of recommendation on Financial Literacy

Carpena, F. S. Cole, J. Shapiro and B. Zia (2011) The ABCs of Financial Literacy - Experimental Evidence on Attitudes, Behaviour and Cognitive Biases, conference paper, World Bank 
Center for International and Regional Studies, (2011). Georgetown University School of Foreign Service in Qatar, Migrant Labor in the Gulf - Working Group Summary Report, Summary Report No. 2

Citizens Advice Belfast, (2010). Financial Inclusion Project 2010

Cheng, E. and Z. Xu (2005). Domestic Money Transfer Services of Migrant Workers in China. Consultative Group to Assist the Poor. http://www.microfinancegateway.org/sites/default/files/mfg-en-paper-domestic-money-transferservices-for-migrant-workers-in-china-2005.pdf

Chin, A., L. Karkoviata, and N. Wilcox (2011). Impact of Bank Accounts on Migrant Savings and Remittances, Evidence from a Field Experiment, University of Houston

Cole, S., T. Sampson and B. Zia (2011). Prices of Knowledge? What Drives Demand for Financial Services in Emerging Markets

Consumer Financial Protection Bureau (2013). Financial Empowerment training for Social Service Programs. A scan of community-based initiatives

Consumers International (2012). The Remittances Game of Chance http://www.consumersinternational.org/media/886482/the\%20remittances\%20game $\% 20 \mathrm{of} \% 20 \mathrm{c}$ $\underline{\text { hance.pdf }}$

Davis, K and M. Jenkinson (2012). Remittances: Their Role, Trends and Australian Opportunities, Australian Centre for Financial Studies

Doi, Y.,McKenzie, D., Zia, B., 2012.Who you trainmatters. Identifying complementary effects of financial education on migrant households. World Bank Policy Research Working Paper, p. 6157

Durana, J. (2010). Financial Literacy Programs for Immigrants, National League of Cities Municipal Action Guide www.nlc.org

European Foundation for Financial Inclusion (2013). Financial inclusion and new means of payment. Qualitative review in five European countries

Frankel, J. A. (2009). Are Bilateral Remittances Countercyclical NBER Working Paper No. 15419

G20/OECD (2013). Advancing National Strategies for Financial Education. A joint publication by Russia's G20 Presidency and the OECD. OECD publishing. http://www.oecd.org/finance/financial-education/G20_OECD_NSFinancialEducation.pdf

Gambetta, R. (2012). Positive Crossroads: Mexican Consular Assistance and Immigrant Integration, Center for Research and Innovation

Garg, N., K. Thacker, S. Bansal, and G. Wright (2009). Migrant Remittances. An Untapped Market. MicroSave India Focus Note 27 http://www.microsave.net/files/pdf/IFN_27_Migrant_Remittances_An_Untapped_Market.pdf

Gibson, J., D. McKenzie, and B. Zia (2012). The impact of financial literacy training for migrants, World Bank Economic Review Vol 28 No 1 pp 130-161 doi:10.1093/wber/lhs034

Grifoni, A. and F-A. Messy (2012). Current Status of National Strategies for Financial Education - A Comparative Analysis and Relevant Practices, OECD Working Paper on Finance, Insurance and Private Pensions, No.16, OECD Publishing 
GIZ (2012).FReDI: Financial Literacy for Remittances and Diaspora Investments. A handbook on Methods for Project Design

Hall, J. (2010). Ten Years of Innovation in Remittance: Lessons Learned and Models for the Future, Multilateral Investment Fund projects, research and dissemination activities from 2000 -2009 http://www.iadb.org/en/publications/publicationdetail,7101.html id=8632\%20\&dcLanguage=en \&dcType=All

Hays, J. (2012) Facts and Details, Migrant Workers in China. Webpage accessed 8 April 2014 http://factsanddetails.com/china/cat11/sub72/item150.html

Hung, A. A. K. Mihaly, and J. K. Yoong, (2009). Federal Financial and Economic Literacy Education Programs, RAND Corporation

IOM, (2009). Inter-regional Policy Dialogue on Remittances and Development - Harnessing the Development Potential of Indonesian Migrant Workers' Remittances (Malaysia-Indonesia Corridor and the Netherlands-Indonesia Corridor as Case Points)

http://www.iom.or.id/reports/eng/Jakarta\%20Policy\%20Dialogue\%20and\%20Annexes\%20200 9.pdf

IFAD, (2009). Remittances: Sending money home, http://www.ifad.org/pub/factsheet/remittances/e.pdf

ILO, (2011). Budget smart - Financial education for migrant workers and their families: training manual / ILO DWT for East and South-East Asia and the Pacific

ILO, (2013) Good practices database- labour migration policies and programmes. http://www.ilo.org/dyn/migpractice/migmain.showPractice?p_lang=en\&p_practice_id=34 Accessed 3 April 2014.

Institute for Latino Studies, (2008). Financial Literacy Among South Bend Latinos, Vol 2, Issue 5 http://latinostudies.nd.edu/publications/pubs/Student_Brief_2.5_Financial_Literacy.pdf

Laureen Laglagaron Migration Policy Institute, (2010). Protection through Integration: The Mexican Government's Effort to Aid Migrants in the United States

Lutheran Immigration and Refugee Service (2012). Financial Literacy for Newcomers. Weaving Immigrant Needs into Financial Education http://www.higheradvantage.org/wpcontent/uploads/2012/05/rw_financial_literacy.pdf

Manila Bulletin (2013). Financial Literacy for the Masses, September 25, 2013. Accessed 4 April 2014 http://www.mb.com.ph/financial-literacy-for-the-masses/

Meiji Fatunla, D, (2013). Financing Social Change. Diaspora Bonds: New Emerging Market Capital, Voices in Society, Volume 3. McKinsey\&Company http://voices.mckinseyonsociety.com/diaspora-bonds-a-new-source-of-capital-for-emergingmarkets/

Mexican Migration to the United States: Policy and Trends, Congressional Research Service

Murphy, R. (2006), Domestic Migrant Remittances in China: Distribution, Channels and Livelihoods, IOM Migration Research Series No. 24, New York: United Nations

Nandhi, M. and K.C. Deepti, (2013). Evolving Participatory Relationships for Uplifting the Urban Poor Rickshaw pullers: Next Step Forward. Institute for Money, Technology and Financial Inclusion. http://www.microfinancegateway.org/sites/default/files/mfg-en-paper-evolving- 
participatory-relationships-for-uplifting-the-urban-poor-rickshaw-pullers-next-step-forward-sep2013.pdf

National Bureau of Statistics of China (2012). Statistical Communique on the 2011 National Economic and Social Development February 22, 2012 http://www.stats.gov.cn/english/NewsEvents/201202/t20120222_26575.html

OECD (2012a) OECD/INFE High-level Principles on National Strategies for Financial Education

OECD (2012b), International Migration Outlook 2012, OECD Publishing. DOI: $\underline{10.1787 / \mathrm{migr} \text { outlook-2012-en }}$

OECD (2014), PISA 2012 Results: Students and Money: Financial Literacy Skills for the 21 st Century (Volume VI), PISA, OECD Publishing. http://dx.doi.org/10.1787/9789264208094-en

Orozco, M. and M. Jewers (2014). Economic Status and Remittance Behaviour among Latin American and Caribbean Migrants in the Post -Recession Period.

Orozco, M., N. Castillo and L. Romei (2010). Toward Financial Independence: Financial Literacy for Remittance Senders and Recipients. The inter-American Dialogue. Washington D.C. 2010 http://www.thedialogue.org/PublicationFiles/Financial\%20literacy\%20paper\%206\%2013\%201 0\%20FINAL.pdf Philippine Statistics Authority (2013), Results from the 2012 Survey on Overseas Filipinos. 2013-116 http://www.census.gov.ph/content/total-number-ofws-estimated22-million-results-2012-survey-overseas-filipinos

Puri, S. and T. Ritzema (1999). Migrant worker remittances, micro-finance and the informal economy: prospects and issues.

Ratha, D. (2011). Comments on Emigration, Labor Markets and Development, World Bank and Migrating out of Poverty Research Consortium, OECD -ISIM Conference on Migration Washington D.C. November 17, 2011

Ratha, D. S. Mohapatra and A. Silwal (2011). The Migration and Remittances Factbook, 2011 http://issuu.com/world.bank.publications/docs/9780821382189?e=1107022/2728353

Ratha, D. and A. Silwal, (2012). Migration and Development Brief 18, The World Bank http://siteresources.worldbank.org/INTPROSPECTS/Resources/3349341110315015165/MigrationandDevelopmentBrief18.pdf

Reserve Bank of India (RBI) (2008). Features of Various Deposit Schemes Available to Non-Resident Indians. Reserve Bank of India Bulletin, June 1.

Reserve Bank of India (2010). Remittances from Overseas Indians: Modes of Transfer, Transaction Cost and Time Taken.

Romagnoli, C. and E. Sie, (2012). Increasing the Impact of Remittances - Financial inclusion of migrant workers and their families back home, The Banking With The Poor Network http://www.bwtp.org/files/Resources/BWTP\%20Bulletins/Bulletin\%20June\%202012\%20Increa sing \%20impact $\% 20 \mathrm{of} \% 20$ Remittances.pdf

Rosenblum, M.R., W. A. Kandel, C. Ribando Seelke and R. E. Wasem, (2012). Mexican Migration to the United States: Policy and Trends, Congressional Research Service

Saavedra, A. (2012). Presentation http://www.oecd.org/daf/fin/financialeducation/ColombiaConferenceRoundtablePresentations.pdf 
SEDI, (2008), Financial Literacy: Resources for Newcomers to Canada

Seshan, G. and D. Yang (2012). Transitional Household Finance: A Field Experiment on the CrossBorder Impacts of Financial Education for Migrant Workers

Seshan, G. and D. Yang (2014). Motivating migrants: A field experiment on financial decisionmaking in transnational households, Journal of Development Economics 108 (2014) 119-127

The Consumer Council (2009). A Map of Financial Capability in Northern Ireland.

The Economist Intelligence Unit, (2008). Building a future back home - Leveraging migrant worker remittances for development in Asia, The Economist

Thimothy, R. and S.K. Sasikumar, (2012). Migration of Women Workers from South Asia to the Gulf http://www.unwomensouthasia.org/2012/migration-of-women-workers-from-south-asia-to-thegulf/

United Nations (2001) Road Map Towards the Implementation of the United Nations Millennium Declaration (2001) http://www.un.org/millenniumgoals/sgreport2001.pdf?OpenElement

UNICEF (2012). Internal Migration in India Initiative: For a Better Inclusion of Internal Migrants in India http://unesdoc.unesco.org/images/0021/002191/219173e.pdf

UNDP (2011). Chapter 4 Remittances, in Towards Human Resilience: Sustaining MDG Progress in an Age of Economic Uncertainty

http://www.undp.org/content/dam/undp/library/Poverty\%20Reduction/Inclusive\%20developme nt/Towards\%20Human\%20Resilience/Towards_SustainingMDGProgress_Ch4.pdf

Usher, E. (2005). The Millennium Development Goals and Migration. International Organization for Migration. Geneva http://www.iom.int/jahia/webdav/site/myjahiasite/shared/shared/mainsite/published_docs/serial _publications/mrs20.pdf

Vezzoli, S and T. Lacroix (2010). Building Bonds for Migration and Development. Diaspora engagement policies of Ghana, India and Serbia. Deutshe Gesellschaft fur Technische Zusammenarbeit (GTZ) GmbH http://www.imi.ox.ac.uk/pdfs/building-bonds-for-migration$\underline{\text { and-development }}$

World Bank (2014). Migration and Development Brief, 22. Migration and Remittances: Recent Developments and Outlook. 


\section{WORKING PAPERS PUBLISHED TO DATE}

The full series is listed below in chronological order. Prior to March 2010, the series was named OECD Working Papers on Insurance and Private Pensions. All working papers can be accessed online at: www.oecd.org/daf/fin/wp.

2014

WP 37: The Bitcoin Question: Currency versus Trust-less Transfer Technology

2013

WP 36: Institutional investors and infrastructure financing

WP 35: Institutional investors and green infrastructure investments: selected case studies

WP 34: Promoting Financial Inclusion through Financial Education

WP 33: Financial Education in Latin America and the Caribbean

WP 32: Pension Fund Investment in Infrastructure: A Comparison between Australia and Canada

WP 31: Policyholder Protection Schemes: Selected Considerations

2012

WP 30: The Effect of Solvency Regulations and Accounting Standards on Long-Term Investing

WP 29: Trends in Large Pension Fund Investment in Infrastructure

WP 28: Communicating Pension Risk to DC Plan Members: The Chilean Case of a Pension Risk Simulator

WP 27: The Role of Funded Pensions in Retirement Income Systems: Issues for the Russian Federation

WP 26: Infrastructure Investment in New Markets: Challenges and Opportunities for Pension Funds

WP 25: The Status of Financial Education in Africa

WP 24: Defining and Measuring Green Investments: Implications for Institutional Investors' Asset Allocations

WP23: The Role of Institutional Investors in Financing Clean Energy

WP22: Defining and Measuring Green Investments: Implications for Institutional Investors' Asset Allocations

WP21: Identification and Assessment of Publicly Available Data Sources to Calculate Indicators of Private Pensions

WP20: Coverage of Private Pensions Systems: Evidence and Policy Options

WP19: Annual DC Pension Statements and the Communications Challenge

WP18: Lessons from National Pensions Communication Campaigns

WP17: Review of the Swedish National Pension Funds

WP16: Current Status of National Strategies for Financial Education 
WP15: Measuring Financial Literacy: Results of the OECD International Network on Financial Education (INFE) Pilot Study

WP14: Empowering Women through Financial Awareness and Education

WP13: Pension Fund Investment in Infrastructure: Policy Actions

WP12: Designing Optimal Risk Mitigation and Risk Transfer Mechanisms to Improve the Management of Earthquake Risk in Chile

2011

WP11: The Role of Guarantees in Defined Contribution Pensions

WP10: The Role of Pension Funds in Financing Green Growth Initiatives

WP9: Catastrophe Financing for Governments

WP8: Funding in Public Sector Pension Plans - International Evidence

WP7: Reform on Pension Fund Governance and Management: The 1998 Reform of Korea National Pension Fund

2010

WP6: Options to Improve the Governance and Investment of Japan's Government Pension Investment Fund

WP5: The New IAS 19 Exposure Draft

WP4: The EU Stress Test and Sovereign Debt Exposures

WP3: The Impact of the Financial Crisis on Defined Benefit Plans and the Need for CounterCyclica Funding Regulations

WP2: Assessing Default Investment Strategies in Defined Contribution Pension Plans

WP1: Framework for the Development of Financial Literacy Baseline Surveys: A First International Comparative Analysis

\section{OECD Working Papers on Insurance and Private Pensions}

2010

WP41: Policy Action in Private Occupational Pensions in Japan since the Economic Crisis of the $1990 \mathrm{~s}$

WP40: Pension Funds' Risk-management Framework: Regulation and Supervisory Oversight

WP38: Managing Investment Risk in Defined Benefit Pension Funds

WP37: Investment Regulations and Defined Contribution Pensions

WP36: Private Pensions and Policy Responses to the Financial and Economic Crisis

WP35: Defined-contribution (DC) arrangements in Anglo-Saxon Countries

WP34: Evaluating the Design of Private Pension Plans

WP33: Licensing Regulation and the Supervisory Structure of Private Pensions

WP32: Pension Fund Investment in Infrastructure

WP31: Pension Coverage and Informal Sector Workers

WP30: Pensions in Africa

WP29: Ageing and the Payout Phase of Pensions, Annuities and Financial Markets 
WP27: Fees in Individual Account Pension Systems

WP26: Forms of Benefit Payment at Retirement

WP25: Policy Options for the Payout Phase

WP24: National Annuity Markets

WP23: Accounting for Defined Benefit Plans

WP22: Description of Private Pension Systems

WP21: Comparing Aggregate Investment Returns in Privately Managed Pension Funds

WP20: Pension Fund Performance

WP19: Coverage of Funded Pension Plans

WP18: Pension Fund Governance

WP17: Funding Regulations and Risk Sharing

WP16: Evaluating the Impact of Risk Based Funding Requirements on Pension Funds

WP15: Governance and Investment of Public Pension Reserve Funds in Selected OECD Countries

WP14: Sovereign Wealth and Pension Fund Issues

2007

WP13: Reforming the Valuation and Funding of Pension Promises

WP12: Pension Fund Investment in Hedge Funds

WP11: Implications of Behavioural Economics for Mandatory Individual Account Pension Systems

WP10: Portfolio Investment in an Intertemporal Setting

WP9: Collective Pension Funds

WP8: Pension Fund Regulation and Risk Management

WP7: Survey of Investment Choice by Pension Fund Members

WP6: Benefit Protection

WP5: Benefit Security Pension Fund Guarantee Schemes

WP4: Governments and the Market for Longevity-Indexed Bonds

WP3: Longevity Risk and Private Pensions

WP2: Policy Issues for Developing Annuities Markets

WP1: Funding Rules and Actuarial Methods 